Canadian

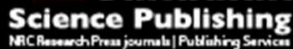

Canadian Geotechnical Journal Revue canadienne de géotechnique

\title{
Runout analysis and mobility observations for large open pit slope failures
}

\begin{tabular}{|r|l|}
\hline Journal: & Canadian Geotechnical Journal \\
\hline Manuscript ID & cgj-2016-0255.R1 \\
\hline Manuscript Type: & Article \\
\hline Date Submitted by the Author: & 18 -Jul-2016 \\
\hline Complete List of Authors: & $\begin{array}{l}\text { Whittall, John; BGC Engineering Inc., } \\
\text { Eberhardt, E.; University of British Columbia, } \\
\text { McDougall, Scott; University of British Columbia, Earth, Ocean and } \\
\text { Atmospheric Sciences }\end{array}$ \\
\hline Keyword: & $\begin{array}{l}\text { Open pit slope failure, Runout analysis, Exclusion zones, Landslide mobility, } \\
\text { Rock slope stability }\end{array}$ \\
\hline
\end{tabular}

SCHOLARONE ${ }^{m}$

Manuscripts 


\section{Runout analysis and mobility observations for large open pit slope}

\section{failures}

John Whittall

BGC Engineering Inc.

Suite $500-980$ Howe Street

Vancouver, BC V6Z 0C8

Canada

jwhittall@bgcengineering.ca

Erik Eberhardt

Geological Engineering, Department of Earth, Ocean, and Atmospheric Sciences

University of British Columbia

2020 - 2207 Main Mall

Vancouver, BC V6T 1 Z4

Canada

erik@eos.ubc.ca

Scott McDougall

Geological Engineering, Department of Earth, Ocean, and Atmospheric Sciences

University of British Columbia

2020 - 2207 Main Mall

Vancouver, BC V6T 1 Z4

Canada

smcdouga@eos.ubc.ca 


\begin{abstract}
Objectively forecasting the runout of a potential open pit slope failure, in addition to identifying the failure itself, is a critical component of a mine's risk management plan. Recent losses arising from large open pit slope failures demonstrate shortcomings in current practice. A dataset of 105 pit slope failures was compiled to compare open pit runout trends against established empirical runout relationships for natural landslides. Fahrböschung angle vs. volume and Fahrböschung angle vs. slope angle relationships provide reasonable runout estimates. Open pit slopes have the advantage of removing the influence of morphological features, vegetation, and liquefiable substrates while controlling the travel path angle and roughness. In such a controlled environment, landslide mobility has a strong sensitivity to slope angle, material properties and fall height, and is only modestly sensitive to volume. A grouping of highly mobile open pit slope cases involving weathered, saturated, collapsible rock mass materials exceed expected runout distances when compared to established runout trends. This suggests mobility for these weaker rock masses is controlled by pore pressures mediating basal friction. The result is that two different runout exceedance trends are observed based on whether the unstable rock mass involves fresh, strong rocks or weathered weak rocks.
\end{abstract}

KEYWORDS: Open pit slope failure, rock slope stability, runout analysis, exclusion zones, landslide mobility 


\section{Introduction}

Recent large open pit slope failures that have caused significant damage to mine infrastructure and equipment demonstrate shortcomings in current practices used to estimate landslide runout and establish exclusion zones for an impending failure (e.g. Pankow et al. 2014; Farina and Coli 2013). Objectively forecasting the zone of impact of a potential slope failure, in addition to identifying the failure itself, is a critical component of a mine's risk management plan, yet few guidelines exist.

In the study of natural landslides empirical runout methods are commonly used to assess runout potential (e.g., Scheidegger 1973; Hsü 1975; Li 1983; Corominas 1996; Iverson et al. 1998; Fannin and Wise 2001; Hunter and Fell 2003). These methods are largely based on field observations and on the analysis of the relationship between the source volume of the landslide and the distance travelled by the debris. Empirical methods are quick, repeatable, and useful for bracketing site conditions where detailed data is limited. The utility of these methods has been recognized for open pit slope failures (Rose 2011), however, existing data sets have solely focused on natural landslide case histories and have not been validated for open pit slope failures.

This paper presents a dataset of 105 extremely rapid ( $>5 \mathrm{~m} / \mathrm{s}$ ) open pit slope failures that have been compiled, analyzed and compared against established empirical runout relationships for natural landslides. Established methods are calibrated to an open pit context and evaluated quantitatively using a cross validation procedure. A discussion of differences between open pit and natural slope runouts highlights possible limitations to the application of these models to open pit slopes, but also identifies useful trends. The absence of natural morphological features, vegetation, and liquefiable substrates in open pits, which are common on natural slopes, also provides an 
opportunity to assess their influences on runout distance, lateral spreading and deposit shape through comparison of the different data sets.

\section{Open pit slope failure database}

A comprehensive public-domain literature search returned ninety-six open pit slope failures that included a runout component, at over fifty different mines. Anonymous sources provided another nine case histories, for a total of 105 open pit slope failures with a runout component. These case histories are presented in a supplement to this paper. Whittall (2015) presents a detailed accounting of each case. The authors infer from anecdotal evidence (the failures ran out) that the landslide motion after detachment was very rapid to extremely rapid and are analogous to Hungr et al.'s (2014) description of rock avalanches. Failures that did not runout, were <40,000 m³, or were retained by effective slope management measures (e.g., Hamel 1970; Brawner 1971; Newcomen and Martin 1988; Martin and Mehr 1993; Newcomen et al. 2003) were excluded from the dataset. Failures where material funneled into collapse features above underground workings related to block caving (e.g., Brummer et al. 2006) were also excluded.

If unspecified, volume estimates are assumed to represent in-place (i.e. un-bulked) source volumes. Where references provide both in-place and bulked failure volumes, plots use the in-place volume for consistency. Wherever possible, additional geometric estimates are taken from satellite imagery, particularly: Google Earth Pro, NASA earth observatory, UNOSAT, Geoscience Australia, ESRI, and hard copy aerial photographs. 


\section{Empirical analysis of data}

\section{Why empirical models?}

Empirical runout models can be useful to perform slope risk assessments and aid decision making in an operating open pit mine. Safety and economic constraints related to personnel withdrawal, equipment, and lost production may leave little time for detailed mechanistic analyses. Treating site-specific influences holistically is appropriate when time and geological uncertainty limit the degree of precision that can be expected. Empirical methods are quick, repeatable, and useful for bracketing site conditions where detailed data are limited.

Numerical runout models (e.g. DAN3D, McDougall and Hungr 2004) are useful tools for studies that require a vulnerability estimate. For example, designing a protection structure or estimating potential damage to infrastructure require an estimate of the destructiveness of the landslide, in addition to delineating the impact area. For landslides in open pit mines, where the vulnerability of workers is near $100 \%$, delineating the runout zone is the main objective and the added complexity of a numerical model is not needed.

\section{Relationships analyzed}

The earliest empirical relationship for landslides was developed by Heim (1932), who proposed that the distance a landslide will travel is proportional to its volume. He equated energy lost to work done, and postulated that the effective friction coefficient of sliding motion should be equal to the ratio of vertical to horizontal displacement. His "Fahrböschung" angle related volume of failed material to the ratio of fall height $(\mathrm{H})$ and horizontal runout distance $(\mathrm{L})$, to graphically describe the 
runout as the inclination of the line connecting the crest of the main scarp and the toe of the deposit (Figure 1).

Several authors have built on Heim's work to incorporate the effects of path morphology and landslide type. Each empirical relationship requires an approximation of source location and travel path, however, disagreement persists on the importance of other parameters. Several established runout relationships were considered in this study using the open pit slope failure database. Full details on each relationship are reported in Whittall (2015).

Volume-based mobility relationships that were analyzed included: Fahrböschung angle (Scheidegger 1975; Li 1983; Nicoletti and Sorriso-Valvo 1991; Corominas 1996; Davidson 2011), runout length (Legros 2002), excessive travel distance (Hsü 1975; see Figure 1), excessive travel distance normalized to total runout length (Nicoletti and Sorriso-Valvo 1991), and inundation area (Li 1983; Iverson et al. 1998).

Hunter and Fell (2003) found that the Fahrböschung angle of flow slides in loose granular fills and waste dumps had almost no dependence on volume; rather, mobility is proportional to the average travel path inclination. Slope angle-based mobility relationships that were analyzed included: Fahrböschung angle (Hunter and Fell 2003), runout length, and excessive travel distance normalized to total runout length.

Other authors studying long runout natural landslides considered landslide motion as an energy balance problem (i.e. the distance a landslide will travel is proportional to the potential energy available). Potential energy-based relationships that were analyzed included: Fahrböschung angle (Howard 1973), runout length (McSaveney 1975), and inundation area (Dade and Huppert 1998). 
Lastly, Staron (2008) suggested that a dimensionless mobility parameter can be derived to describe the shape and thickness of the deposit, providing a relative measure of mobility. Staron plotted runout length normalized to thickness (L/V $1 / 3$ ) against inundation area normalized to volume $\left(\mathrm{A} / \mathrm{V}^{2 / 3}\right)$ and found a positive correlation in log-log space.

\section{Relationships omitted}

Compared with natural slope conditions, an open pit has the advantage of removing morphological features, vegetation, and liquefiable substrate while controlling travel path angle and roughness. Methods developed for channeled flow (Benda and Cundy 1990; Fannin and Rollerson 1993; Zimmerman 1997), small volumes involving less than 1,000 $\mathrm{m}^{3}$ (Finlay et al. 1999; Rickenmann 1999), and volume balance (Cannon 1993; Fannin and Wise 2001) do not lend themselves well to a mining context because they involve factors that are irrelevant for open pit slope failures. Relationships describing the centre of mass of the source and deposit were also excluded. The position of the centre of mass is difficult to estimate and is inconsequential to equipment or workers compared with the position of the leading edge of the landslide.

Boulder rollout methods were also excluded but deserve future consideration. Literature and satellite imagery that were available for this study did not have sufficient detail to describe the boulder rollout.

\section{Mobility relationship comparison}

\section{Model uncertainty}

Validating established empirical runout models to open pit data was achieved by evaluating whether the data conforms to the constraints of the method: 
- Does the empirically predicted runout length provide a reasonable match to the observed runout?

- If not, do they conservatively over predict runout or hazardously under predict runout?

- Can we integrate pit slope failure runout into a risk management plan as we can with natural landslides?

This evaluation was achieved by superimposing the open pit data on the established best-fits, comparing the datasets, plotting a best-fit regression, then quantitatively validating the relationship to obtain a prediction quality, and estimating the parameter sensitivity for each relationship.

Validation was assessed using $k$-fold cross validation (Stone 1974). Cases are grouped randomly into $k$ equal-sized folds. Each fold retains a distinct subset of cases as a validation set and the remaining cases are the training set. The training-validation process is repeated $k$ times. This method is well-suited to small datasets that cannot afford to lose data to a validation set. All cases have a role in both training and validation, and each case is used for validation only once.

Root mean square error (RMSE) and normalized index (NI) are calculated for each fold and parameter variance, as in Equations 1 and 2, respectively:

$$
\begin{array}{r}
R M S E=\sqrt{\frac{\sum_{1}^{n}(\text { Xpredicted }- \text { Xobserved })^{2}}{n}} \\
N I=\frac{\text { Xpredicted }- \text { Xobserved }}{\text { Xobserved }} \times 100
\end{array}
$$

Normalization can be positive or negative depending on whether or not the model results in over- or under-estimation of runout. A positive NI means that the mobility relationship overestimates runout, whereas a negative NI means that the mobility relationship underestimates runout. Using RMSE and NI together provides extra context for goodness of fit. For example, a 
runout estimation error of 100 m may only represent an error of a few percent if the case in question involves a large, long runout landslide.

Table 1 is a comparison of the mobility relationships calibrated to pit slope failures. Figure 2 is a description of the prediction quality for each mobility relationship. The box is the first and third quartile error bisected by the median error. The whisker bars contain the $5^{\text {th }}$ and $95^{\text {th }}$ percentile. Fahrböschung angle vs. volume and Fahrböschung angle vs. original slope angle mobility relationships provide reasonably similar prediction to the observed runout and appear to be roughly normally distributed. Single parameter relationships, those based on runout length alone, present more asymmetric error distributions with long tails.

\section{Parameter uncertainty}

An open pit slope has the advantage of having a well-defined geometry, deformation monitoring, and structural and geotechnical models. As such, parameter selection is less complicated than for natural landslides. While uncertainty remains regarding the rupture surface and source volume, a priori estimates of slope angle, crest location, material properties, and failure mechanism can be reasonably constrained. To test how sensitive the models are to their inputs, parameters were varied individually for every case over a range of up to $100 \%$ of their reported value. The RMSE and NI were then calculated for each parameter variance.

Whittall (2015) provides comparison plots of model sensitivity to volume, slope angle, and fall height, respectively. The parameter uncertainty assessment indicates:

- The single parameter relationships (i.e., L vs. V, Le vs. V) are highly sensitive to the input estimate. 
- Fahrböschung angle and Le/L are only modestly dependant on volume and more sensitive to slope angle.

- Fahrböschung angle and excessive travel distance relationships have fall height in their equations and are proportionately sensitive (1:1).

- All of the remaining mobility relationships are also sensitive to fall height.

The sensitivity to fall height is expected because the travel length and drop height for an object traveling down an incline are dependant variables. Contrasting with natural landslide research, empirical models using this dataset are most sensitive to slope angle and fall height, rather than volume.

\section{Recommended relationships}

\section{Fahrböschung angle vs. volume}

The Fahrböschung angle is the simplest parameter to apply and particularly amenable to rapidly developing failure scenarios in complex ground. Figure 3 is the open pit dataset superimposed on established natural rock avalanche Fahrböschung relationships developed by Scheidegger (1975), Li (1983), and Davidson (2011). All three natural rock avalanche relationships are an assemblage of rock avalanche datasets with various geology, failure mechanisms, geomechanical properties, slope configurations, and path morphology. The holistic nature of these models captures the inherent complexity of each event. This, however, leaves significant scatter.

The landslide runout trends in Figure 3 can be seen to generally agree with the open pit data set, although it should be emphasized that the fits are plotted in log-log space. Scheidegger's (1975) and Davidson's (2011) fit reasonably capture the mean trend while Li's (1983) fit under predicts runout in a significant number of the cases. 
The linear regression for the open pit data has an RMSE of $109 \mathrm{~m}$ and mean NI of $3.1 \%$. Error appears normally distributed but contains tails, as can be seen in Figure 4. The outlier cases are influenced by obstructions at the opposing wall (less mobile cases) or flow-like behaviour (more mobile cases). The effect of obstruction at opposing walls and pit-bottom sumps is addressed later in the paper. Closer interrogation of the material behaviour reveals two trends based on the rock mass characteristics and slope angle, as shown in Figure 5. Li's regression reasonably describes the less mobile trend, while Scheidegger and Davidson's regression under predict runout for the more mobile trend. Equations 3 and 4 are best fit least squares regression lines for the two mobility trends for cases involving fresh strong rock and weathered weak rock, respectively.

$$
\begin{aligned}
& \frac{\mathrm{H}}{L}=0.559 \text { volume } \\
& \frac{\mathrm{H}}{\mathrm{L}}=0.150
\end{aligned}
$$

Volume units in equations 3 and 4 are million cubic metres. Separating the data into two trends improves the correlation, with an RMSE of $48 \mathrm{~m}(0.8 \%)$ for the less mobile trend and $61 \mathrm{~m}$ (1.5\%) for the more mobile trend. Figure 6 shows the combined error distribution for the two datasets.

\section{Fahrböschung angle vs. slope angle}

Hunter and Fell (2003) recognized that the runout of waste dump flow slides is sensitive to path angle and insensitive to volume. Their dataset included path confinement conditions and volume ranges similar to those seen with open pit failures $\left(10^{3}\right.$ to $\left.10^{7} \mathrm{~m}^{3}\right)$. Figure 7 presents a linear space Fahrböschung angle vs. original wall angle plot for the pit slope failure dataset. Note that Hunter and Fell (2003) used the angle of the topography, not the angle of the waste dump face. 
Like the waste dump trend, the $\mathrm{H} / \mathrm{L}$ ratio for the open pit failure dataset increases with the slope angle without the separate trends seen in the volume-dependent relationship, and fits sufficiently well to plot in linear space.

The $\mathrm{x}$-axis of Figure 7 is the bench stack angle if the case was contained to one set of benches; otherwise, it is the overall slope angle.

More data is required to assess the suitability of this method for slopes steeper than $50^{\circ}$ $\left(\tan 50^{\circ} \approx 1.2\right)$. These steeper cases illustrate an important limitation of this relationship and perhaps an additional threshold exists at $50^{\circ}$ where mobility remains relatively constant. Goodness of fit statistics and the best-fit regression shown in Equation 5 exclude these cases.

$$
\frac{H}{L}=0.488 \tan (\text { slope angle })+0.117
$$

The remaining data have an RMSE of $87 \mathrm{~m}$ and a mean NI of $1.6 \%$ with normally distributed error (Figure 8).

This relationship has a similar model uncertainty to its volume counterpart but much lower parameter uncertainty. This model provides a useful check for geometrically complex landslides where volume is difficult to estimate and pit walls are inclined less than $50^{\circ}$. The user needs to decide on the relevant wall angle: the bench stack angle if the source and deposit are likely to be contained on the same bench stack, or the overall angle if the travel path is likely to overrun ramps and reach the pit floor. A mechanistic explanation $\mathrm{H} / \mathrm{L}$ increasing with slope angle is presented later in this paper. 


\section{Inundation area vs. volume}

Estimating a two-dimensional deposit area is a useful addition to locating the distal toe of the deposit. Established inundation area relationships (Li 1983; Iverson et al. 1998) have used datasets of various landslide classifications to compare both reach and spread of landslides. The maximum inundation area of an average flow can be reasonably described in log-log space as $\mathrm{A}=$ $\mathrm{cV}^{2 / 3}$. Griswold and Iverson (2008) compared lahar, debris flow, and rock avalanche cases to show planimetric shape is scale invariant, but different landslide types require unique values of the coefficient c. Figure 9 is the open pit data plotted with Li (1983) and Griswold and Iverson's (2008) regressions.

Open pit landslides show the same self-similar deposit shape (slope=2/3), but with a less mobile y-intercept (c=6). Inundation area was only available in $47(45 \%)$ of the cases compiled in the database because it is rarely reported in the literature and high resolution satellite imagery is only recently available. The RMSE and mean NI for this index is $4.6 \times 10^{4} \mathrm{~m}^{2}$ and $10.1 \%$, respectively, uniformly distributed with outliers (Figure 10).

Predictable error, albeit large, is still useful. Inundation area combined with other mobility relationships is useful to map a hazard back from the estimated deposit toe. This relationship is recommended to complement a runout distance model to create a hazard map. It may also be useful to assess the degree of spreading when the landslide is obstructed by an opposing wall.

\section{Performance of empirical runout relationships}

Researchers of natural landslides have searched for trends in natural landslide behaviour and explanations for exceptional cases. They can be grouped into endogenic (within the system) or exogenic (outside the system) influences (Alexander 1993). Endogenic influences are properties of 
the landslide: its size, the nature of the materials, failure mechanism, fall height, and travel path angle. Exogenic influences are properties of the environment: liquefiable substrate, confinement or obstruction, triggering event, and surface water or glaciers along the travel path. An open pit has the advantage, relative to natural landslides, of controlling most exogenic influences. As such, the dataset presented here is a well constrained subset of landslides with known external influences. This provides an opportunity to ask: Which parameters have the most influence on landslide mobility if external influences like material entrainment are removed or controlled?

\section{Slope angle}

The separate trends in the Fahrböschung angle vs. volume plot have a clear dependence on original slope angle, as shown in Figure 11. This plot shows that steeper slopes having smaller failures and shorter runout distances. The typical constant slope angle of a pit wall, relative to natural landscapes and flat pit bottoms, is likely the cause. Abrupt path angle changes are an obstruction to the travel path and consume energy. Equation 6 is the sliding resistance (T) to a frictional sliding block.

$$
T=\rho h\left(g \cos \alpha+a_{c}\right) \tan \varphi_{b}
$$

When the sliding path is curved, bed-normal stress is a function of centripetal acceleration $\left(a_{c}\right)$, shown in Equation 7, which in turn is a function of velocity (v) and radius of curvature (R).

$$
a_{c}=\frac{v^{2}}{R}
$$

A shallower slope creates a larger radius (Figure 12), decreasing the centripetal acceleration, and therefore presents less basal resistance or energy consumption. The same effect 
occurs with lateral spreading (McDougall and Hungr 2004). If everything else is equal, steeper slopes produce shorter runout lengths and less spread.

\section{Volume}

Most researchers studying natural landslide mobility agree that volume has an influence on runout. However the volume of pit slope failures is a narrow subset of the natural landslide spectrum, biased towards the lower volume end. The usefulness of established volume-dependent relationships must be tempered by this contextual difference.

Figure 13 shows the Fahrböschung angle minus the slope angle, as defined in the inset, versus volume for the open pit failure cases. This is not a mobility relationship; it is a comparison of the relative parameter sensitivity. Subtracting the tangent of the slope angle from H/L is an attempt to remove the influence of slope angle in Figure 11. The resulting horizontal trend infers that $\mathrm{H} / \mathrm{L}$ is less sensitive to volume than slope angle, and mobility of this dataset is only modestly dependent on volume. This is consistent with the parameter sensitivity analysis presented in Whittall (2015).

It can be asserted that steeper walls often contain higher quality rock and that higher quality rock may minimize the failure volume. The increase in slope angle that opposes mobility may be counterbalanced by the volume induced reduction in mobility. In fact there is a strong covariance of original slope angle and source volume for pit slope failures (Whittall 2015), both contribute to the momentum of the landslide. However, a steep wall angle does not infer a small failure volume. In this dataset, H/L has an inverse relationship with volume but it appears less influential than slope angle because of the narrow range of source volumes, compared to natural landslides. 


\section{Fall height}

Several researchers (Hsü 1975; Davies 1982; Legros 2002) point to fall height as simply contributing to data scatter. Although its role is clear in a mathematical energy balance, it is less so for proxies like the Fahrböschung angle. Legros and others show that a plot of runout length vs. volume gives a better correlation and suggest that natural landslides rapidly dissipate the kinetic energy gained during initial fall and "forget" the initial fall height (Legros 2002).

Figure 14 shows a similar plot with the open pit data. Several smaller volume cases (e.g., $97,105)$ that behaved as expected have become outliers, which is conspicuous. The RMSE is $116 \mathrm{~m}$ and mean $\mathrm{NI}$ is $13 \%$, with scatter close to $400 \mathrm{~m}$ for the low volume cases. Figure 15 is the lognormal distribution of the error showing a general under prediction.

Corominas (1996) used a comparison of fall height to horizontal travel length to show that, if two identical failures occur from different fall heights, the one with the larger drop will travel farthest. Figure 16 is a similar plot derived from the open pit data that clearly shows that fall height has an influence on runout length. The difference between open pit and natural landslide mobility dependence on fall height may be the same abrupt change in slope angle discussed above, enhanced by the lack of liquefiable substrate. A natural landscape typically has a gradual transition from mountain side to a gently inclined overburden-rich valley floor. The landslide may entrain and rapidly load the valley substrate, producing an undrained condition and contributing to a large increase in L while only modestly increasing H (Hungr and Evans 2004). These natural valley conditions are not available in an open pit. 


\section{Spread}

Considering Li’s (1983) trends in Figure 3 and Figure 9, established runout relationships appear to over predict the planimetric deposit area of pit slope failures but under predict the location of the distal deposit toe. The mechanisms that control runout length and spread appear to act differently in an open pit.

There are two common deposit shapes. Figure 17 depicts deposit width measurements taken at $0 \%, 10 \%, 25 \%, 50 \%, 75 \%, 90 \%$ and $100 \%$ of the deposit length, normalized to deposit length to provide an aspect ratio. The first shape (black) is a wide talus cone sitting at its angle of repose. Typically, these talus deposits form an apron hung on or below the source. A more prevalent shape (red) is a long, thin deposit where the width is similar to the source width. Figure 18 is a comparison of the degree of spreading, the ratio of mean source and deposit areas, versus volume symbolized by broad material categories. The spread is generally centralized around 1 , indicating that $\mathrm{Area}_{\mathrm{deposit}} \sim \mathrm{Area}_{\text {source }}$ and that this data does not show significant spread. For context, Abele (1974) found that natural rock avalanches in the Alps spread between ratios of 1 and 10 depending on material type, and that spread decreased with volume.

Staron's (2008) dimensionless inundation area to runout length relationship is another useful comparison of deposit aspect. Deposits in the bottom left corner of the graph include those that neither ran far nor covered a large area, creating a thick, less-mobile deposit. Cases in the top right corner ran far and spread to form a thin veneer. Figure 19 is the open pit data fit to Staron's (2008) model with natural landslide cases to show his intended observation. There is no discernable trend in the open pit data and it tends to cluster to a small range. Data clustering at $\mathrm{x}=6$ is encouraging for the $A=6 V^{2 / 3}$ relationship developed earlier. A useful by-product is that the data is 
concentrated around the lower left corner of the plot, indicating thicker deposits with similar aspect ratios but distinctly different behaviour than natural landslides.

Figure 20 is a cumulative frequency plot of inundation area normalized to volume. Normalization is required because the open pit dataset only spans the lower volume range of the natural landslides. The open pit and natural landslide datasets occupy different ranges of spread values; the open pit data plots farthest left and sub-vertically. This result indicates that they spread less per unit volume than natural landslides and that there is not significant variety in deposit shapes. The verticality of the open pit data makes it impossible to make statistical comparisons. Nonetheless, qualitatively, Figure 20 shows that open pit failures spread less than natural landslides and into more predictable shapes.

A logical explanation for less spread in this dataset is that a pit bottom has finite available space to spread. An obstruction by the opposing wall or water will cause thickening of the deposit, rather than spread, reducing the inundation area and perhaps channeling material into a longer runout. Most cases in the dataset, however, were not obstructed.

Theoretically, spread in landslides without path constrictions is controlled by normal and transverse shear stress and the internal and basal shear resistance of the landslide (McDougall and Hungr 2004). A physical justification for the lower inundation area but longer reach of this dataset is the travel path inclination and lack of liquefiable substrate; the same mechanism as above. A pit wall transitions abruptly to a flat, rough floor composed of materials of a similar strength. This expends centrifugal force and limits the spread of the landslide. There may also be high longitudinal pressures that develop through the abrupt slope transition. As such, the landslide may deposit thicker, or the tip may travel farther with less spread. 


\section{Material properties}

The separate trends in the Fahrböschung angle vs. volume relationship are partly a consequence of different material properties. Heim's (1932) original Fahrböschung angle proposition was an energy balance, where the average friction coefficient is equal to the ratio of vertical and horizontal displacement. It does not attempt to describe the path or dynamics of the flow. It is not surprising that materials with different frictional characteristics have different mobility.

In this dataset, geology and rock mass characteristics are generally well known. The less mobile trend contains failures in fresh, strong rocks that is described well by Li's (1983) regression. These rocks failed as dry, frictional materials. The volume increase resulting from dilation and bulking as the rock slope fails and passes from intact rock to debris reduces the ability of pore pressures to increase within the sliding mass (Hungr and Evans 2004). Combined with the lack of liquefiable substrate, the basal friction angle is not significantly mediated by pore pressure. Deposits appear granular and sit at approximately $37^{\circ}$.

A more mobile Fahrböschung angle vs. volume trend is observed for weathered, clay rich rocks and poorly cemented sedimentary rocks. These materials are often characterized using soil constitutive models. A hypothesis for the difference in behaviour compared with fresh, strong rocks is that these materials have a collapsible structure, creating undrained strength conditions when sheared. Hunter and Fell (2003) and Locat and Leroueil (1997) provide natural landslide precedents for different runout behaviour in dilative versus contractive materials.

Many of the literature sources of the open pit failure cases note a significant precipitation event, high or perched water tables, and/or deficiencies in surface water management as 
contributing to the failures. Forty-seven of the cases (including all but two of the most mobile cases) assign a precipitation event as the failure trigger, despite pit depressurization measures being in place. Detailed pore pressure data is not available; however, reduced effective stresses in response to elevated pore pressures in the pit walls seem likely given these anecdotes.

\section{Poorly cemented granular materials}

Poorly cemented sedimentary rocks often have high porosities, either due to the depositional environment (e.g., Boron, cases 13 to 24), alteration (e.g., Gold Quarry, case 38), or mining disturbance (e.g., Grasberg, case 47). Minor amounts of cohesion are suggested as holding together a disorganized house of cards clay-rich structure with void space available for contraction. Hutchinson (2002) and Sassa (2000) proposed that such materials crush and contract in shear, generating excess pore pressure at the rupture surface. When saturated, granular contracting materials subjected to shear at a high strain rate behave undrained, even if initially in a drained condition (Ladd 1991).

Sassa (2000) demonstrated the role of pore pressure in shearing granular materials and coined the term sliding surface liquefaction. A loose granular material forced to shear will want to contract. This effect is enhanced if the rock has cohesion to lose. If the rock is saturated, as many of the triggering events imply, the volume change cannot occur and pore pressures increase. In turn, effective stress and basal resistance decrease.

\section{Clay-bearing fault zones}

Sheared discontinuities, and their infill, have a shear strength at or near their residual values. Any cohesion that existed from previous over-consolidation will be destroyed during 
shearing. In the case of joint infill, Barton (1974) showed that infilling is expected to act in a normally consolidated state.

\section{Weathered materials}

Saprolite and other residual soils are generally more heterogeneous than sedimentary soils and do not have a stress history. These weathered materials are not composed of individually deposited discrete particles, but rather a degradation of a previously intact block. The void ratio to effective stress plot, and normal- versus over-consolidated states, are not applicable to residual soils. Rather, Wesley (2010) showed disturbing or remoulding residual soils causes them to disintegrate and contract, much the same as Sassa's (2000) grain crushing experiment.

\section{Pore pressure dissipation in clay-rich materials}

Iverson (1997) showed that there is a negative correlation between the rate of pore pressure dissipation ( $\mathrm{t}_{\text {diff }}$ ) and compressibility and permeability of the material (Equation 7$)$. He showed that clay-rich materials with excess pore pressures dissipate their pore pressure orders of magnitude slower than dilative materials, leaving interstitial fluid available to mediate the basal friction:

$$
t_{\text {diff }}=\frac{Y^{2} \mu}{k E}
$$

where $\mathrm{Y}$ is a normalizing length term, $\mu$ is the viscosity of the fluid, $k$ is the permeability of the material, and $\mathrm{E}$ is the stiffness modulus.

Either from the addition of total stress (through redistribution and concentration of stresses during pit excavation) or by decreasing effective stresses (precipitation triggers), clay-rich 
materials forced to rapidly shear will behave in an undrained manner. Large natural landslides show this effect where fluidization occurs from a relatively small volume of water initially present in the failing mass (Legros 2002). The initial failure mass may also load the travel path, increasing the pore pressure and decreasing the shear resistance. Rapid undrained loading is a common long runout mechanism in natural debris avalanches (Hungr and Evans 2004).

This mechanism does not dismiss the possibility of other site-specific influences on runout. A unique combination of material and slope properties are, however, difficult to estimate in an emergency and may lead to misguided deterministic use of these empirical relationships. Pore pressure mediating basal friction provides a reasonable holistic explanation for long runout landslides and can be identified using parameters practitioners can map.

\section{Distinguishing mobility trends}

Figure 21 is a design chart to choose the appropriate mobility category (for use with Figure 5) using intact strength (ISRM 1978), weathering grade (ISRM 1978), porosity, and disturbance. Here, shear strength and porosity are used as key indicator properties for dilative versus contractive behaviour. The user should apply the properties of the worst $10 \%$ of the rock mass.

\section{Travel path obstruction}

Obstruction or deflection at the opposing pit wall can introduce curvature to the travel path or bulking of the deposit toe. Nineteen $(18 \%)$ of the pit slope failures ran to the opposing wall or a constructed berm. In the case of a runout length prediction exceeding the available linear distance across the pit floor, an area vs. volume prediction is useful to estimate the degree of spread at the opposing wall. 
Six (6\%) of the pit slope failures ran into water. These are classified as unobstructed in Whittall (2015) because the water bodies are typically shallow sumps or ponding at the pit bottom. The authors acknowledge impact with a water body will expend momentum and have an effect on mobility. Given the shallow depth, limited areal extent, and stagnancy of these sumps and ponds, the effect is likely minor compared to natural landslides impacting lakes and rivers.

Channeling at corners or along ramps may change the flow shape of pit slope failures, however, not to the extent that valleys or gullies in natural landscapes would. Nonetheless, narrowing the data to more homogeneous obstruction populations can be a useful exercise to further identify the cause of the separate trends in Figure 5. Figure 22 compares the open pit dataset with Corominas' (1996) regressions for rockfall/rock avalanche with path obstruction.

The inverse relation between Fahrböschung angle and volume remains regardless of path attribute. An inflection appears at 1,000,000 $\mathrm{m}^{3}$ where the data follows Corominas' (1996) deflected regression line more closely. This change may indicate a change in the mechanism of motion where the mass becomes flow-like, as postulated for natural landslides (Hsü 1975; Davidson 2011). The runout of obstructed landslides is shorter than non-obstructed landslides, however, these cases still fall within the scatter of the data and do not stratify themselves into a separate trend.

\section{Failure mechanism}

The failure mechanisms of the pit slope failure cases did not significantly influence mobility because the data is a narrow subset of possible landslide types. Finlay et al. (1999) and Hunter and Fell (2003) also found that narrowing the context to small debris flows and mine waste dumps, respectively, removed the variety of mechanisms and limited its effect. 
Figure 23 is the Fahrböschung angle vs. volume relationship symbolized by failure mechanism. The eight toppling failures in this dataset are less mobile than the general trends in Figure 5 but within the scatter of the other cases. Seventeen of the highly mobile cases were planar failures in poorly cemented sandstones. It is difficult to determine whether the planar failure mechanism in these cases had a greater influence than the inherent low material strength and collapsible structure. The other eleven (of twenty-eight) planar failures occurred in stronger and less porous materials and did not show exceptional mobility characteristics. Rotational and debris slides plot in the more mobile end of the scatter, which suggests that material characteristics (dilative versus contractive) have a larger effect on mobility than structural control and kinematics.

\section{Piecemeal and successive failures}

Eighteen (17\%) of the pit slope failures involved at least two distinct events. The toppling failure at Hogarth (case 49), for example, detached from the wall in a piecemeal fashion, resulting in a short runout. Experiences from the 1991 Randa rockslide (Eberhardt et al. 2004) demonstrate that simple empirical runout models using the total cumulative volume can over predict mobility in such cases. A continuous series of low volume failures will likely produce a short runout.

Conversely, remobilized debris from previous failures can be more mobile than the original landslide. Colluvium left with a loose, disorganized structure may readily collapse in shear and behave in an undrained manner. The 2005 La Conchita landslide (Jibson 2005), for example, remobilized colluvium left by a 1995 event. Despite being much smaller in volume, the 2005 event exceeded runout expectations and overtopped protection structures designed based on experiences from the first landslide. 
Often rockfall and bench-scale failures are precursors for a larger event. Exclusion zones should be based on the cumulative volume regardless of how piecemeal a failure may appear. Runout estimates for pit slopes in colluvium should use the more mobile (Trend 2) mobility relationship.

\section{Influences on landslide mobility}

Prominent theories for surprisingly long runout landslides include: interstitial fluids (Iverson 1997; Wang and Sassa 2003), air entrapment (Shreve 1968), mechanical fluidization reducing basal friction (Heim 1932; McSaveney 1978; Davies 1982; Campbell 1989); air (Kent 1966) or acoustic (Melosh 1979) fluidization reducing internal friction; and dynamic fragmentation (Davies and McSaveney 2002).

Studying landslide mobility in an open pit removes topographic confinement (gullies, valleys) and liquefiable substrate (soil, surface water, ice). The remaining long runout mechanisms, if they exist, should still be operating. When we limit both the endogenic and exogenic influences, mobility has a strong sensitivity to slope angle, material characteristics, and fall height, and is only modestly sensitive to volume. Even when unobstructed, the exceptional spread seen in many natural landslides does not appear to exist in an open pit (Figure 20). The highly mobile cases occurred on shallow slopes (Figure 7 and Figure 11) composed of saturated, collapsible materials (Trend 2 in Figure 5). This result implies that mobility is controlled by pore pressure mediating basal friction (Abele 1974; Iverson 1997; Wang and Sassa 2003), and the much more impressive spread and fluidity seen in natural landslides is related to the conditions not present in open pits, i.e., rapid loading of a liquefiable substrate (Hungr and Evans 2004) and topographic channelization. 


\section{Conclusions}

Fahrböschung angle vs. volume and Fahrböschung angle vs. slope angle relationships calibrated to open pit slope failures provide reasonable runout estimates and are useful for creating exclusion zones. An inundation area vs. volume relationship can be a useful complement to provide estimates of the zone of impact relative to the expected toe location. These relationships are sensitive to slope angle, the nature of the material, and fall height, and only modestly sensitive to volume.

Open pit landslides appear to deposit predictably-shaped debris aprons that either hang below the source in a $37^{\circ}$ talus cone or flow into a continuous pile, thinning away from the source. Compared to natural landslides, they form thicker, more predictably-shaped deposits with less lateral spread. Set in a probabilistic framework, the empirical relationships presented in this paper can be used to objectively define exclusion zones and integrate runout into a mine's emergency response plan.

\section{Database extension}

This study relied on published failure descriptions written from an operations and slope stability perspective. Only a few of the publications from which the data was extracted explicitly discuss runout. Building a dataset with greater diversity is desirable but likely only possible with access to a broader experience base. The authors would like to extend an invitation for others to share their case histories and pit slope runout experience. Confidentiality can be maintained by omitting reference to location or source of the data, if necessary. Correspondence to this effect can be made via email to Mr. John Whittall jwhittall@bgcengineering.ca. 


\section{Acknowledgments}

Funding for this research was provided through an NSERC Industrial Post-Graduate Scholarship partnered with BGC Engineering Inc. The authors would also like to thank Professors Oldrich Hungr and Doug Stead for their insights and discussions that helped to advance this work. Two anonymous reviewers provided excellent feedback.

\section{References}

Abele, G. 1974. Bergstürze in den Alpen: Munich, Wissen-schaftliche Alpenvereinshefte, v.25, p. 230.

Alexander, D.E. 1993. Natural Disasters. University College London Press, London, United Kingdom, p. 632.

Barton, N. R. 1974. Estimating the shear strength of rock joints. Advances in Rock Mechanics, 2(Part A), 219-221.

Benda, L. E., and Cundy, T. W. 1990. Predicting deposition of debris flows in mountain channels. Canadian Geotechnical Journal, 27(4), 409-417.

Brawner, C. O. 1971. Case studies of stability on mining projects. In Stability in Open Pit Mining. Edited by C.O. Brawner and V. Milligan, Society of Mining Metallurgy, New York. pp. 205-226.

Brawner, C. O., and Stacey, P. F. 1979. Hogarth pit slope failure, Ontario, Canada. In Rock slides and avalanches. Edited by B. Voight. Elsevier, Amsterdam, pp. 691-707.

Brummer, R. K., Li, H., Moss, A., and Casten, T. 2006. The transition from open pit to underground mining: an unusual slope failure mechanism at Palabora. In Proceedings of Slope Stability 2006:

International Symposium on Rock Slope Stability in Open Pit Mining and Civil Engineering, Cape Town, South Africa, 3-6 April 2006, South African Institute for Mining and Metallurgy, Johannesburg, pp. 411420.

Campbell, C. S. 1989. Self-lubrication for long runout landslides. The Journal of Geology, 97, 653-665.

Cannon, S. H. 1993. An empirical model for the volume-change behavior of debris flows. In Proceedings of the National Conference on Hydraulic Engineering, San Francisco, California, 25-30 July 1993. American Society of Civil Engineers, pp. 1768-1773.

Corominas, J. 1996. The angle of reach as a mobility index for small and large landslides. Canadian Geotechnical Journal, 33(2), 260-271.

Dade, W. B., and Huppert, H. E. 1998. Long-runout rockfalls. Geology, 26(9), 803-806. 
Davidson, C. 2011. Rock Avalanches. M.Eng. thesis (unpublished), Department of Geological Engineering, The University of British Columbia, Vancouver, B.C.

Davies, T. R. 1982. Spreading of rock avalanche debris by mechanical fluidization. Rock Mechanics, 15(1), 9-24.

Davies, T. R., and McSaveney, M. J. 2002. Dynamic simulation of the motion of fragmenting rock avalanches. Canadian Geotechnical Journal, 39(4), 789-798.

Eberhardt, E., Stead, D., and Coggan, J. S. 2004. Numerical analysis of initiation and progressive failure in natural rock slopes - the 1991 Randa rockslide. International Journal of Rock Mechanics and Mining Sciences, 41(1), 69-87.

Fannin, R. J., and Rollerson, T. P. 1993. Debris flows: some physical characteristics and behaviour. Canadian Geotechnical Journal, 30(1), 71-81.

Fannin, R. J., and Wise, M. P. 2001. An empirical-statistical model for debris flow travel distance.

Canadian Geotechnical Journal, 38(5), 982-994.

Farina P, and Coli, N. 2013. Efficient real time stability monitoring of mine walls : The Çöllolar mine case study. Int. Min. Congr. Exhib. Turkey, Antalya: 2013, pp. 111-7.

Finlay, P. J., Mostyn, G. R., and Fell, R. 1999. Landslide risk assessment: prediction of travel distance. Canadian Geotechnical Journal, 36(3), 556-562.

Griswold, J. P., and Iverson, R. M. 2008. Mobility statistics and automated hazard mapping for debris flows and rock avalanches. U.S. Geological Survey Scientific Investigation Report 2007-527, U.S. Geological Survey, Reston, Virginia, 59 p.

Hamel, J. V. 1970. The Pima Mine slide, Pima County, Arizona. In Abstracts with Programs, Geological Society of America, 2(5), 335.

Heim, A. 1932. Landslides and human lives (Bergstruz and Menchen leben). Translated by N.

Skermer, BiTech Publishers, Vancouver, B.C., 195 p.

Howard, K. A. 1973. Avalanche mode of motion: Implications from lunar examples. Science, 180(4090): 1052-1055.

Hsü, K. J. 1975. Catastrophic debris streams (sturzstroms) generated by rockfalls. Geological Society of America Bulletin, 86(1), 129-140.

Hungr, O., and Evans, S. G. 2004. Entrainment of debris in rock avalanches: an analysis of a long run-out mechanism. Geological Society of America Bulletin, 116(9-10), 1240-1252.

Hungr, O., Leroueil, S., and Picarelli, L. 2014. The Varnes classification of landslide types, an update. Landslides, 11(2), 167-194.

Hunter, G., and Fell, R. 2003. Travel distance angle for" rapid" landslides in constructed and natural soil slopes. Canadian Geotechnical Journal, 40(6), 1123-1141. 
Hutchinson, J. N. 2002. Chalk flows from the coastal cliffs of northwest Europe. Reviews in Engineering Geology, 15, 257-302.

ISRM. 1978. Suggested methods for determining the uniaxial compressive strength and deformability of rock materials. International Journal of Rock Mechanics and Mining Sciences, 16, 135-140.

Iverson, R. M. 1997. The physics of debris flows. Reviews of geophysics, 35(3), 245-296.

Iverson, R. M., Schilling, S. P., and Vallance, J. W. 1998. Objective delineation of lahar-inundation hazard zones. Geological Society of America Bulletin, 110(8), 972-984.

Jibson, R. W. 2005. Landslide hazards at La Conchita, California U.S. Geological Survey, Open File Report 2005-1067, U.S. Geological Survey, Reston, Virginia, 12 p.

Kent, P. E. 1966. The transport mechanism in catastrophic rock falls. The Journal of Geology, 74, 79-83.

Ladd, C. C. 1991. Stability evaluations during staged construction, Journal of Geotechnical Engineering, 117, 540-615.

Legros, F. 2002. The mobility of long-runout landslides. Engineering Geology, 63(3), 301-331.

Li, T. 1983. A mathematical model for predicting the extent of a major rockfall. Zeitschrift für Geomorphologie, 24, 473-482.

Locat, J., and Leroueil, S. 1997. Landslide stages and risk assessment issues in sensitive clays and other soft sediments. In Proceedings of the International Workshop on Landslide Risk Assessment, Honolulu, Hawaii, 19-21 February 1997. Balkema, Rotterdam, pp. 261-270.

Martin, D. C., and Mehr, E. F. 1993. Assessment of slope deformation and deep-seated instability in the Cassiar open pit. CIM Bulletin, 86(972), 58-67.

McDougall, S., and Hungr, O. 2004. A model for the analysis of rapid landslide motion across threedimensional terrain. Canadian Geotechnical Journal, 41(6), 1084-1097.

McDougall, S. 2006. A new continuum dynamic model for the analysis of extremely rapid landslide motion across complex 3d terrain. Ph.D. Thesis, Department of Geological Engineering, The University of British Columbia, Vancouver, B.C.

McSaveney, M. J. 1975. The Sherman Glacier rock avalanche of 1964: its emplacement and subsequent effects on the glacier beneath it. Ph.D. thesis, Department of Geology and Mineralogy, The Ohio State University, Columbus, Ohio.

McSaveney, M.J. 1978. Sherman Glacier rock avalanche, Alaska, USA. In Rockslides and Avalanches 1, Natural Phenomena. Edited by B Voight. Elsevier. pp. 197-258.

Melosh, H. J. 1979. Acoustic fluidization: A new geologic process? Journal of Geophysical Research, 84(B13), 7513-7520.

Newcomen, H. W., and Martin, D. C. 1988. Geotechnical assessment of the southeast wall slope failure at Highmont Mine, British Columbia. CIM Bulletin, 81, 71-76. 
Newcomen, H. W., Shwydiuk, L., and Maggs, C. S. 2003. Managing pit slope displacements: Highland Valley Copper's Lornex pit southwest wall. CIM Bulletin, 96(1071), 43-48.

Nicoletti, P. G., and Sorriso-Valvo, M. 1991. Geomorphic controls of the shape and mobility of rock avalanches. Geological Society of America Bulletin, 103(10), 1365-1373.

Pankow, K.L., Moore J.R., Mark Hale, J., Koper, K.D., Kubacki, T., Whidden, K.M., and McCarter, M.K. 2014. Massive landslide at Utah copper mine generates wealth of geophysical data. GSA Today 2014;24: pp.4-9. doi:10.1130/GSATG191A.1.

Rickenmann, D. 1999. Empirical relationships for debris flows. Natural hazards, 19(1), 47-77.

Rose, N.D. 2011. Investigating the Effects of Mining-Induced Strains on Open Pit Slopes. In Proceedings Slope Stability 2011: International Symposium on Rock Slope Stability in Open Pit Mining and Civil Engineering, Vancouver, B.C., 18-21 September 2011. Canadian Rock Mechanics Association, paper 237.

Sassa, K. 2000. Mechanism of flows in granular soils. In Proceedings of GeoEng2000, Melbourne, Australia, 19-24 November 2000. Australian Geomechanics Society, Perth, pp. 1671-1702.

Scheidegger, A. E. 1973. On the prediction of the reach and velocity of catastrophic landslides. Rock mechanics, 5(4), 231-236.

Shreve, R. L. 1968. Leakage and fluidization in air-layer lubricated avalanches. Geological Society of America Bulletin, 79(5), 653-658.

Staron, L. 2008. Mobility of long-runout rock flows: a discrete numerical investigation. Geophysical Journal International, 172(1), 455-463.

Stone, M. 1974. Cross-validatory choice and assessment of statistical predictions. Journal of the Royal Statistical Society. Series B (Methodological), 111-147.

Wang, G., and Sassa, K. 2003. Pore-pressure generation and movement of rainfall-induced landslides: effects of grain size and fine-particle content. Engineering geology, 69(1), 109-125.

Wesley, L. D. 2010. Geotechnical engineering in residual soils. John Wiley and Sons Ltd., New York. p. 243.

Whittall, J. R. 2015. Runout exceedance prediction for open pit slope failures. M.A.Sc. Thesis, Department of Geological Engineering, The University of British Columbia, Vancouver, B.C.

Zimmermann, M., Mani, P., and Romang, H. 1997. Magnitude-frequency aspects of alpine debris flows. Eclogae Geologicae Helvetiae, 90(3), 415-420. 
Figure Captions

Figure 1 Schematic definition of the Fahrböschung angle and excessive travel distance

Figure 2 Prediction quality of runout relationships calibrated to open pit landslides

Figure 3 Open pit data with Scheidegger (1975), Li (1983), and Davidson (2011) best fit Fahrböschung angle vs. volume regressions

Figure 4 Error distribution for Fahrböschung angle vs. volume mobility relationship

Figure 5 Open pit data with Fahrböschung angle vs. volume relationship. Two separate mobility trends emerge based on rock mass characteristics.

Figure 6 Error distribution for stratified Fahrböschung angle vs. volume mobility relationship

Figure 7 Open pit data with Fahrböschung angle vs. slope angle mobility relationship

Figure 8 Error distribution for Fahrböschung angle vs. slope angle mobility relationship

Figure 9 Open pit data with inundation area vs. volume mobility relationship

Figure 10 Error distribution for inundation area vs. volume mobility relationship

Figure 11 Fahrböschung angle vs. volume mobility relationship symbolized by slope angle

Figure 12 Exaggerated schematic of slope angle's effect on centripetal acceleration

Figure 13 Open pit data with Fahrböschung angle normalized to slope angle. Note there is no relationship with volume when normalized to original slope angle.

Figure 14 Open pit data with runout length vs. volume mobility relationship

Figure 15 Distribution of error for runout length vs. volume mobility relationship

Figure 16 Comparison of open pit failure fall height to runout length

Figure 17 Map of deposit aspect observations

Figure 18 Degree of spreading in open pit slope failures

Figure 19 Open pit data with dimensionless mobility relationship

Figure 20 Comparison of open pit failure and natural rock avalanche deposit spreads

Figure 21 Rock mass characteristics mobility trends matrix for use with Figure 5

Figure 22 Open pit data compared to Corominas (1996) path obstruction Fahrböschung angle vs. volume mobility relationship

Figure 23 Fahrböschung angle vs. volume relationship symbolized by failure mechanism 


\section{Pit slope dataset references}

Almenara, J.R., Poespito, T.S., and Lelono, H.D. 2011. Batu Hijau Open Pit Slope Design Based on Geotechnical Models and Past Performance. In Proceedings Slope Stability 2011: International Symposium on Rock Slope Stability in Open Pit Mining and Civil Engineering, Vancouver, B.C., 18-21 September 2011. Canadian Rock Mechanics Association, paper 236.

Armstrong, J. 2011. Management of progressive slope deformation at Goldstrike - Challenges and lessons learned. Presentation at 2011 Barrick Geomechanics and Hydrogeology Conference, Kalgoorlie, Australia.

Armstrong, J., and Rose, N. D. 2009. Mine operation and management of progressive slope deformation on the south wall of the Barrick Goldstrike Betze-Post Open Pit. In Slope Stability 2009: Proceedings of the International Symposium on Rock Slope Stability in Open Pit Mining and Civil Engineering, Santiago, 9-11 November 2009, CSIRO publishing.

Asof, M., Dyah Hastuti, E. W., Manuhutu, H. I., and Nasution, Y. 2010. The study of landslide using slope stability radar within failure SS_P4_028 in PT Newmont, Nusa Tenggara Barat, Indonesia. In Proceedings of the Twin International Conferences on Geotechnical and Geo-Environmental Engineering, Seoul, South Korea, 24-25 June 2010, pp. 177-186.

Atkins, J. T., and Pasha, M. A. 1973. Controlling Open-Pit Slope Failures at Shirley Basin Mine. In Proceedings of the AIME Annual Meeting, Chicago, Illinois, $20 \mathrm{p}$.

Aydan, O., Ulusay, R., Kumsar, H., and Ersen, A. 1996. Buckling Failure at an Open-pit Coal Mine. In Proceedings of International society of rock mechanics EUROCK 96, Turin, Italy, 2-5 September 1996, Balkema, Rotterdam, pp. 641-648.

Bates, E., St Louis, R., Douglas, S., and Sheets, R. 2006. Slope Monitoring and Failure Mitigation Techniques Applied in the Gold Quarry Open Pit. In Proceedings of Golden Rocks 2006: The 41st US Symposium on Rock Mechanics, Golden, Colorado, 17-21 June 2006. American Rock Mechanics Association, pp. 1047-1059.

Behbahani, S.S. 2012. A model for unloading of sliding mass in Angooran mine. M.Sc. thesis, Department of mining engineering, science and research branch, Islamic Azad University, Tehran, Iran.

Bertuccioli, P., Distefano П, Е. F., and Federico, G. 1992. Initial Deformations in High Cuts in Overconsolidated Jointed Clays. In Proceedings of the $6^{\text {th }}$ International Conference on Landslides, Christchurch, New Zealand, 10-14 February 1992. Balkema, Rotterdam, pp. 1265-1270.

Brawner, C. O. 1971. Case studies of stability on mining projects. In Stability in Open Pit Mining. Edited by C.O. Brawner and V. Milligan, Society of Mining Metallurgy, New York. pp. 205-226.

Brawner, C. O., Stacey, P. F., and Stark, R. 1975. A successful application of mining with pit wall movement. In Proceedings of Canadian Institute of Mining annual western meeting, Edmonton, Alberta, October 1975, 20 p.

Brawner, C. O., and Stacey, P. F. 1979. Hogarth pit slope failure, Ontario, Canada. In Rock slides and avalanches. Edited by B. Voight. Elsevier, Amsterdam, pp. 691-707. 


\section{Supplementary Data for cgj-2016-0255}

Brawner, C.O. 1982. Stabilization of Rock Slopes. In Stability in Surface Mining, Vol. 3. Edited by C.O. Brawner. SME-AIME, New York, pp. 289-310.

Broadbent, C. D., and Zavodni, Z. M. 1982. Influence of rock structure on stability. In Stability in Surface Mining, Vol. 3. Edited by C.O. Brawner. SME-AIME, New York, pp. 7-18.

Brummer, R. K., Li, H., Moss, A., and Casten, T. 2006. The transition from open pit to underground mining: an unusual slope failure mechanism at Palabora. In Proceedings of Slope Stability 2006: International Symposium on Rock Slope Stability in Open Pit Mining and Civil Engineering, Cape Town, South Africa, 3-6 April 2006, South African Institute for Mining and Metallurgy, Johannesburg, pp. 411420.

Clough, G. W., West, L. J., and Murdock, L. T. 1979. Pit slope performance in shale, Wyoming, USA. In Rock Slides and Avalanches, Volume 2. Edited by B. Voight. Elsevier, Amsterdam, pp. 667-689.

Coates, D. F., Yu, Y., and Gyenge, M. 1979. A Case History of Pit Slope Design. In Proceedings of the $4^{\text {th }}$ International Society for Rock Mechanics Congress, Montreux, Switzerland, 2-8 September 1979, International Society of Rock Mechanics, pp. 591-595.

Coulthard, M. A., Lucas, D. S., and Fuller, P. G. 2004. Application of UDEC to a stress-related mine slope failure al Leigh Creek, South Australia. In Proceedings of the Symposium on Numerical Modelling of Discrete Materials, Bochum, Germany, 29 September - 1 October 2004. Balkema, Rotterdam, pp. 289296.

Cremeens, J., Gilbride, L., Cellan, R., and Cox, A. 2000. Numerical Simulation of Complex Slope Displacement. In Proceedings of the 4th North American Rock Mechanics Symposium, Seattle, Washington, 31 July - 3 August 2000. Balkema, Rotterdam, pp. 561-567.

Cremeens, J.A. 2003. Geologic controls on complex slope displacement at the Pitch reclamation project. In Engineering Geology in Colorado: Contributions, Trends, and Case Histories. Edited by Douglas Boyer. Association of Engineering Geologists, 14 p.

D’Elia, B., Esu, F., Marchetti, S., and Totani, G. 1996. In situ DMT testing and observations in landslide area in overconsolidated jointed clay. In Proceedings of the 7th International Symposium on Landslides, Volume 3, Trondheim, Norway, 17-21 June 1996. CRC Press, pp. 121-125.

da Franca, P.R.B. 1997. Analysis of slope stability using limit equilibrium and numerical methods with case examples from the Aguas Claras mine, Brazil. Ph.D. thesis, Department of Mining Engineering, Queen's University, Kingston, Canada.

Darbor, M., Jalalifar, H., and Moarefv, P. 2010. A developed technique to predict support system for plane failure; case study: lead-zinc Angoran mine. In Proceedings of the 6th Asian Rock Mechanics Symposium, New Delhi, India, 23-27 October 2010. International Society for Rock Mechanics, 9 p.

Day, A. P., and Seery, J. M. 2007. Monitoring of a large wall failure at Tom Price Iron Ore Mine. In Proceedings of Slope Stability 2007: International Symposium on Rock Slope Stability in Open Pit Mining and Civil Engineering, Perth, Australia, 12-14 September 2007, Australian Centre for Geomechanics, Perth, pp. 333-340.

de Jager, A., and Ludik, H. 2006. High-wall control at Anglo Gold Ashanti, Navachab mine. In Proceedings of Slope Stability 2006: International Symposium on Rock Slope Stability in Open Pit 
Mining and Civil Engineering, Cape Town, South Africa, 3-6 April 2006, South African Institute for Mining and Metallurgy, Johannesburg, pp. 509-524.

Dight, P.M. 2006. Pit wall failures on "unknown" structures. The Journal of the South African Institute of Mining and Metallurgy, 106, 451-458.

Dyke, G. 2009. Best practice and new technology in open pit mining geotechnics: Geita gold mine, Mali a case study. In Proceedings of the World Gold Conference, Gauteng, South Africa, 26-30 October 2009. South African Institute of Mining and Metallurgy, Johannesburg, pp. 169-176.

Farina, P., Coli, N., Yön, R., Eken, G., and Ketizmen, H. 2013. Efficient real time stability monitoring of mine walls: the Çöllolar mine case study. In Proceedings of the International mining congress and exhibition of Turkey, Antalya, pp. 111-117.

Fisher, B. R. 2009. Improved characterization and analysis of bi-planar dip slope failures to limit model and parameter uncertainty in the determination of setback distances. Ph.D. thesis, Department of Geological Engineering, The University of British Columbia, Vancouver, B.C.

Ginting, A., Stawski, M., and Widiadi, R. 2011. Geotechnical risk management and mitigation at Grasberg Open Pit, PT Freeport Indonesia. In Proceedings Slope Stability 2011: International Symposium on Rock Slope Stability in Open Pit Mining and Civil Engineering, Vancouver, B.C., 18-21 September 2011. Canadian Rock Mechanics Association, paper 122.

Goldberg, W.C., and Frizzell, E.M. 1989. A case history of pit slope monitoring and back analysis, Berkeley pit, Butte, Montana. In Proceedings of the SME Annual Meeting, Las Vegas, Nevada, 27 February - 2 March 1989. Society of Mining Engineers, Littleton, Colorado, 8 p.

Golder Associates. 2011. Geotechnical evaluations and design recommendations (revised): Permanente quarry reclamation plan update, Santa Clara County, California. Available from http://www.scribd.com/doc/62193085/Volume-I-07-C-Geotechnical-Report-amp-Figures

Hibert, C., Ekström, G., and Stark, C. P. 2014. Dynamics of the Bingham Canyon Mine landslides from seismic signal analysis. Geophysical Research Letters, 41(13), 4535-4541.

Hormazabal, E., Veramendi, R., Barrios, J., Zuniga, G., and Gonzalez, F. 2013. Slope design at Cuajone Pit, Peru. In Proceedings of the International Symposium on Slope Stability in Open Pit Mining and Civil Engineering, Brisbane, Australia, 25-27 September 2013. Australian Centre for Geomechanics, Perth, pp. 527-540.

Hutchison, B.J., MacQueen, G.K, Dolting, S.L., and Morrison, A.T. 2013. Drape mesh protection at the Savage River Mine, Tasmania. In Proceedings of the International Symposium on Slope Stability in Open Pit Mining and Civil Engineering, Brisbane, Australia, 25-27 September 2013. Australian Centre for Geomechanics, Perth, pp. 1011-1020.

Jhanwar, J. C., and Thote, N. R. 2011. Slope failures in the opencast coal mines of Wardha Valley Coalfield in central India: a study. Rock mechanics and rock engineering, 44(5), 635-640.

Joass, G.G., Dixon, R., Sikma, T., Wessels, S.D.N., Lapwood, J., and de Graaf, P.J.H. 2013. Risk management and remediation of the north wall slip, West Angelas Mine, Western Australia. In Proceedings of the International Symposium on Slope Stability in Open Pit Mining and Civil 
Engineering, Brisbane, Australia, 25-27 September 2013. Australian Centre for Geomechanics, Perth, pp. 995-1010.

Johnson, J. D., Fergusson, D., and Guy, G. 2007. Risk Based Slope Design for Opencast Coal Mines at Rotowaro, Huntly, New Zealand. In Slope Stability 2007: Proceedings of the 2007 International Symposium on Rock Slope Stability in Open Pit Mining and Civil Engineering, Perth, Australia, 12-14 September 2007, Australian Centre for Geomechanics, Perth, pp. 157-170.

Jones, E. 2011. Development of the Wallaby Pit instabilities. In Mining in Saprolites short course at Slope Stability 2011: International Symposium on Rock Slope Stability in Open Pit Mining and Civil Engineering, Vancouver, B.C., 18-21 September 2011. Canadian Rock Mechanics Association.

Jones, E., Andrews, P., and Holley, S. 2011. The Wallaby Mine: Maintaining pit wall stability for continued underground mining. In Proceedings Slope Stability 2011: International Symposium on Rock Slope Stability in Open Pit Mining and Civil Engineering, Vancouver, B.C., 18-21 September 2011. Canadian Rock Mechanics Association, paper 188.

Jiang, S., Kong, X., Ye, H., and Zhou, N. 2013. Groundwater dewatering optimization in the Shengli no. 1 open-pit coalmine, Inner Mongolia, China. Environmental sciences, 69(1), 187-196.

Kayesa, G. 2006. Prediction of slope failure at Letlhakane Mine with the Geomos Slope Monitoring System. In Proceedings of the International Symposium on Stability of Rock Slopes in Open Pit Mining and Civil Engineering, Cape Town, South Africa, 3-6 April 2006. South African Institute of Mining and Metallurgy, Johnannesburg, pp. 605-622.

Kelly, C., Wu, K., Ward, B., and Cook, R. 2002. Highwall stability in an open pit stone operation. In Proceedings of the 21st International Conference on Ground Control in Mining, Morgantown, West Virginia, 6-8 August 2002. West Virginia University, pp. 228-235.

Kennedy, B. A., Niermeyer, K. E., and Fahm, B. A. 1969. A major slope failure at the Chuquicamata Mine, Chile. Min Eng AIME, 12(12), 60.

Kramadibrata, S., Wattimena, R. K., Sidi, I. D., Azizi, M. A., and Adriansyah, Y. 2012. Open Pit Mine Slope Stability and Uncertainty. In Proceedings of the $7^{\text {th }}$ Asian Rock Mechanics Symposium, Seoul, South Korea, 15-19 October 2012. International Society for Rock Mechanics, pp. 1233-1240.

Lynch, R. A., and Malovichko, D. A. 2006. Seismology and slope stability in open pit mines. In Proceedings of Slope Stability 2006: International Symposium on Rock Slope Stability in Open Pit Mining and Civil Engineering, Cape Town, South Africa, 3-6 April 2006, South African Institute for Mining and Metallurgy, Johannesburg, pp. 375-390.

Macrae, A. M. 1985. Case History of an Open Pit Coal Mine Slope Failure at Luscar Alberta. M.Eng. thesis, Department of civil engineering, The University of Alberta, Edmonton, Alberta.

MacQueen, G.K., Salas, E.I., and Hutchison, B.J. 2013. Application of radar monitoring at Savage River Mine, Tasmania. In Proceedings of the International Symposium on Slope Stability in Open Pit Mining and Civil Engineering, Brisbane, Australia, 25-27 September 2013. Australian Centre for Geomechanics, Perth, pp. 1011-1020. 
Martin, C.D., and Stacey, P.F. 2013. Pit slopes in weathered and weak rocks. In Proceedings of the International Symposium on Slope Stability in Open Pit Mining and Civil Engineering, Brisbane, Australia, 25-27 September 2013. Australian Centre for Geomechanics, Perth, pp. 3-28.

Mercer, K.G. 2006. Investigation into the time dependent deformation behaviour and failure mechanisms of unsupported rock slopes based on the interpretation of observed deformation behaviour. Ph.D. thesis, Faculty of Engineering and the Built Environment, The University of Witwatersrand, Johannesburg, South Africa.

Miller, V. J. 1982. The Northeast Tripp Slide - A 11.7 Million Cubic Meter Wedge Failure at Kennecott's Nevada Mine Division. In Proceedings of the 3rd International Conference on Stability in Surface Mining, Vancouver, B.C., 1-3 June 1981. SME-AIME, New York, pp. 725-743.

Moarefvand, P., Ahmadi, M., and Afifipour, M. 2011. Unloading scheme to control sliding mass at Angouran open pit mine, Iran. In Proceedings of the 12th ISRM Congress, Beijing, China, 16-21 October 2011. Taylor and Francis Group, London, pp. 1963-1966.

Moffett, J.R., and Adkerson, R.C. 2003. $3^{\text {rd }}$ Quarter 2003 Earnings Conference Call - Grasberg open pit material slippage overview.

Moharana, A., and Lonergan, J. 2014. Managing the medium term mine scheduling challenges at Bingham Canyon mine after the slide. The Mintec series: medium term challenges.

Moore, M. 2003. Fatal error left miners at mercy of landslide. The Sydney Morning Herald, 1 November 2003.

Naismith, W. A., and Wessels, S. D. N. 2005. Management of a major slope failure at Nchanga Open Pit, Chingola, Zambia. Journal of the South African Institute of Mining and Metallurgy, 105(9), 619.

Nasuf, E., Eskikaya, S., Bilgin, N., Copur, H., and Kont, R. 1993. Slope stability analysis in K.B.I Murgul Copper Mine of Turkey. In Proceedings of the International Symposium on Assessment and Prevention of Failure Phenomena in Rock Engineering, Istanbul, Turkey 5-7 April 1993. Balkema, Rotterdam, pp. 549554.

Oldcorn, R.C., and Seago, R. 2007. Understanding the bigger picture: Interpretation of geological structure in open pit rock slope stability. In Slope Stability 2007: Proceedings of the 2007 International Symposium on Rock Slope Stability in Open Pit Mining and Civil Engineering, Perth, Australia, 12-14 September 2007, Australian Centre for Geomechanics, Perth, pp. 449-462.

Pankow, K. L., Moore, J. R., Hale, J. M., Koper, K. D., Kubacki, T., Whidden, K. M., and McCarter, M. K. 2014. Massive landslide at Utah copper mine generates wealth of geophysical data. GSA Today, 24(1), 4-9.

Reid, G., and Stewart, D. 1986. A large scale toppling failure at Afton. In Proceedings International Symposium on Geotechnical Stability in Surface Mining, Calgary, Alberta, 6-7 November 1986. CRC Press, pp. 215-223.

Rippere, K., Sun, Y., and Tejada, L. 1999. Geotechnical monitoring and modeling at Cuajone open-pit mine. In Proceedings of Mining Science and Technology symposium, Beijing, China, 29-31 August 1999. CRC Press, pp. 379-383. 


\section{Supplementary Data for cgj-2016-0255}

Rose, N. D., and Sharon, R. P. 2000. Practical rock slope engineering designs at Barrick Goldstrike. In Slope Stability in Surface Mining. Edited by W.A. Hustrulid, M.K McCarter, and D.J.A. Van Zyl. Society for Mining, Metallurgy, and Exploration, Inc, Littleton, Colorado, pp.213-218.

Rose, N. D., and Hungr, O. 2007. Forecasting potential slope failure in open pit mines - contingency planning and remediation. International Journal of Rock Mechanics and Mining Sciences, 44, 308-320.

Rose, N.D. 2011. Investigating the Effects of Mining-Induced Strains on Open Pit Slopes. In Proceedings Slope Stability 2011: International Symposium on Rock Slope Stability in Open Pit Mining and Civil Engineering, Vancouver, B.C., 18-21 September 2011. Canadian Rock Mechanics Association, paper 237.

Ross, B., and Sutherlin, C. 2015, March 11. Lessons from Kennecott Utah Copper's Manefay slide [Webinar]. In SME Annual Meeting 2015. Available from https://smenet.webex.com.

Roux, R., Terbrugge, P., and Badenhorst, F. 2006. Slope Management at Navachab Gold Mine, Namibia. In Proceedings of Slope Stability 2006: International Symposium on Rock Slope Stability in Open Pit Mining and Civil Engineering, Cape Town, South Africa, 3-6 April 2006, South African Institute for Mining and Metallurgy, Johannesburg, pp. 579-594.

Seegmiller, B. L. 1972. Rock stability analysis at Twin Buttes. In Proceedings of the $13^{\text {th }}$ Symposium on Rock Mechanics, Urbana, Illinois, 30 August - 1 September 1971. American Society of Civil Engineers, pp. 511-536.

Sharon, R.P. 2011. Challenges of open pit mine development in weak rocks. In Mining in Saprolites short course at Slope Stability 2011: International Symposium on Rock Slope Stability in Open Pit Mining and Civil Engineering, Vancouver, B.C., 18-21 September 2011. Canadian Rock Mechanics Association.

Sharon, R.P., Bywater, A., and Greenhill, P. 2013. Cowal Gold Mine (CGM. In Guidelines for evaluating water in pit slope stability. Edited by G. Beale and J. Read. CSIRO publishing, Clayton, Australia, pp. $520-525$.

Sheets, R.J. 2011. Lessons learned from Carlin Formation slope instability at the Gold Quarry operation. In Mining in Saprolites short course at Slope Stability 2011: International Symposium on Rock Slope Stability in Open Pit Mining and Civil Engineering, Vancouver, B.C., 18-21 September 2011. Canadian Rock Mechanics Association.

Sheets, R. J., Douglas, S. J., St Louis, R. M., and Bailey, J. A. 2014. Remediation of large-scale slope failures and impact on mine development at the Gold Quarry Mine. Mining Engineering, 66(11), 57-64.

Sheng, Z., and Lui, Z. 1995. Analysis of the landslide at a limestone open pit mine in China. In Proceedings of the 8th ISRM Congress, Tokyo, Japan, 25-29 September 1995. International Society for Rock Mechanics, pp. 437-439.

Sjöberg, J. 1996. Large scale slope stability in open pit mining-a review. Technical Report 1996:10T, Lulea University of Technology, Division of Rock Mechanics, Lulea, Sweden, p. 229.

Speight, H.E. 2002. Solving a slope stability problem at the Cleo open pit in Western Australia. Snowdon mining industry consultants. 
Srikant, A., Brannon, C., Flint, D. C., and Casten, T. 2007. Geotechnical characterization and design for the transition from the Grasberg open pit to the Grasberg block cave mine. In Proceedings of the 1st Canada-US Rock Mechanics Symposium, Vancouver, B.C., 27-31 May 2007. American Rock Mechanics Association, pp.1277-1286.

Sullivan, T.D. 2006) Pit Slope Design and Risk - A View of the Current State of the Art. In Proceedings of Slope Stability 2006: International Symposium on Rock Slope Stability in Open Pit Mining and Civil Engineering, Cape Town, South Africa, 3-6 April 2006, South African Institute for Mining and Metallurgy, Johannesburg, pp. 51-80.

Szwedzicki, T. 2001. Geotechnical precursors to large-scale ground collapse in mines. International Journal of Rock Mechanics and Mining Sciences, 38(7), 957-965.

Tannant, D. D., and LeBreton, R. 2007. Footwall slope slab failure at a mountain coal mine. In Proceedings of the 1st Canada-US Rock Mechanics Symposium, Vancouver, B.C., 27-31 May 2007. American Rock Mechanics Association, pp.156-164.

Terbrugge, P. J., and Hanif, M. 1981. Discussion of a large scale failure on the footwall of the Nchanga open pit, Zambia. In ISRM International Symposium, Tokyo, Japan, 21-24 September 1981. Balkema, Rotterdam, pp. 1499-1501.

Terbrugge, P. J., Wesseloo, J., Venter, J., and Steffen, O. K. H. 2006. A risk consequence approach to open pit slope design. Journal of the South African Institute of Mining and Metallurgy, 106(7), 503-514.

Tutluoglu, L., Öge, I. F., and Karpuz, C. 2011. Two and three dimensional analysis of a slope failure in a lignite mine. Computers and Geosciences, 37(2), 232-240.

Turk, N., and Koca, M.Y. 1993. Influence of historic landslides in design of the Borax open pit mine. In Proceedings of the International Symposium on Assessment and Prevention of Failure Phenomena in Rock Engineering, Istanbul, Turkey 5-7 April 1993. Balkema, Rotterdam, pp. 573-578.

UNOSAT. 2011. Post-Landslide Assessment for Çöllolar Coalfield Kahramanmaras, Turkey. United Nations Institute for Training and Research.

Venter, J., Kuzmanovic, A., and Wessels, S.D.N. 2013. An evaluation of the CUSUM and inverse velocity methods of failure prediction based on two open pit instabilities in Pilbara. In Proceedings of the International Symposium on Slope Stability in Open Pit Mining and Civil Engineering, Brisbane, Australia, 25-27 September 2013. Australian Centre for Geomechanics, Perth, pp. 1061-1076.

Voight, B., and Kennedy, B. A. 1979. Slope failure of 1967-1969, Chuquicamata mine, Chile. Rockslides and avalanches, 2, 595-632.

Weichert, D., Horner, R. B., and Evans, S. G. 1994. Seismic signatures of landslides: The 1990 Brenda Mine collapse and the 1965 hope rockslides. Bulletin of the Seismological Society of America, 84(5), 1523-1532.

Wessels, S. D. N. 2009. Monitoring and Management of a Large Open Pit Failure. M.Sc.E thesis, Faculty of Engineering and the Built Environment, University of Witwatersrand, Johannesburg, South Africa.

Wyllie, D. C. 1980. Toppling rock slope failures examples of analysis and stabilization. Rock Mechanics, 13(2), 89-98. 
Yamaguchi, U., and Shimotani, T. 1986. A case study of slope failure in a limestone quarry. International Journal of Rock Mechanics and Mining Sciences 23(1), 95-104.

Yanbo, Z., Zhanjin, L., and Zhiqiang, K. 2010. Analysis on landslide catastrophe mechanism and landslip forecasting for open-pit coal mine. In Proceedings of the International Symposium on In-situ Rock Stress, Beijing, China, 25-27 August 2010. Taylor and Francis Group, London, pp. 401-405.

Yang, D. Y., Brouwer, K. J., Sheets, R. J., St Louis, R. M., and Douglas, S. J. 2011a. Large-Scale Slope Instability at the Gold Quarry Mine, Nevada. In Proceedings Slope Stability 2011: International Symposium on Rock Slope Stability in Open Pit Mining and Civil Engineering, Vancouver, B.C., 18-21 September 2011. Canadian Rock Mechanics Association, paper 252.

Yang, D.Y., Mercer, R.A., Brouwer, K.J., and Tomlinson, C. 2011b. Managing pit slope stability at the Kemess South Mine - changes over time. In Proceedings Slope Stability 2011: International Symposium on Rock Slope Stability in Open Pit Mining and Civil Engineering, Vancouver, B.C., 18-21 September 2011. Canadian Rock Mechanics Association, paper 271.

Yost, R. R. 2009. The Time Value of Risk: A Case Study at the Boron Operations Open Pit Mine. Ph.D. thesis, Department of Mining, Geology, and Geological Engineering, The University of Arizona, Tucson, Arizona.

Zhou, C., Li, X., Qin, S., Qiu, D., Wu, Y., Xiao, Y., and Zhou, J. 2008. Automatic monitoring system for high-steep slope in open-pit mine based on GPS and data analysis. In Proceedings of the International Conference on Earth Observation Data Processing and Analysis, Wuhan, China, 28-29 December 2008. American Society of Civil Engineers. pp. 4098-4103. 


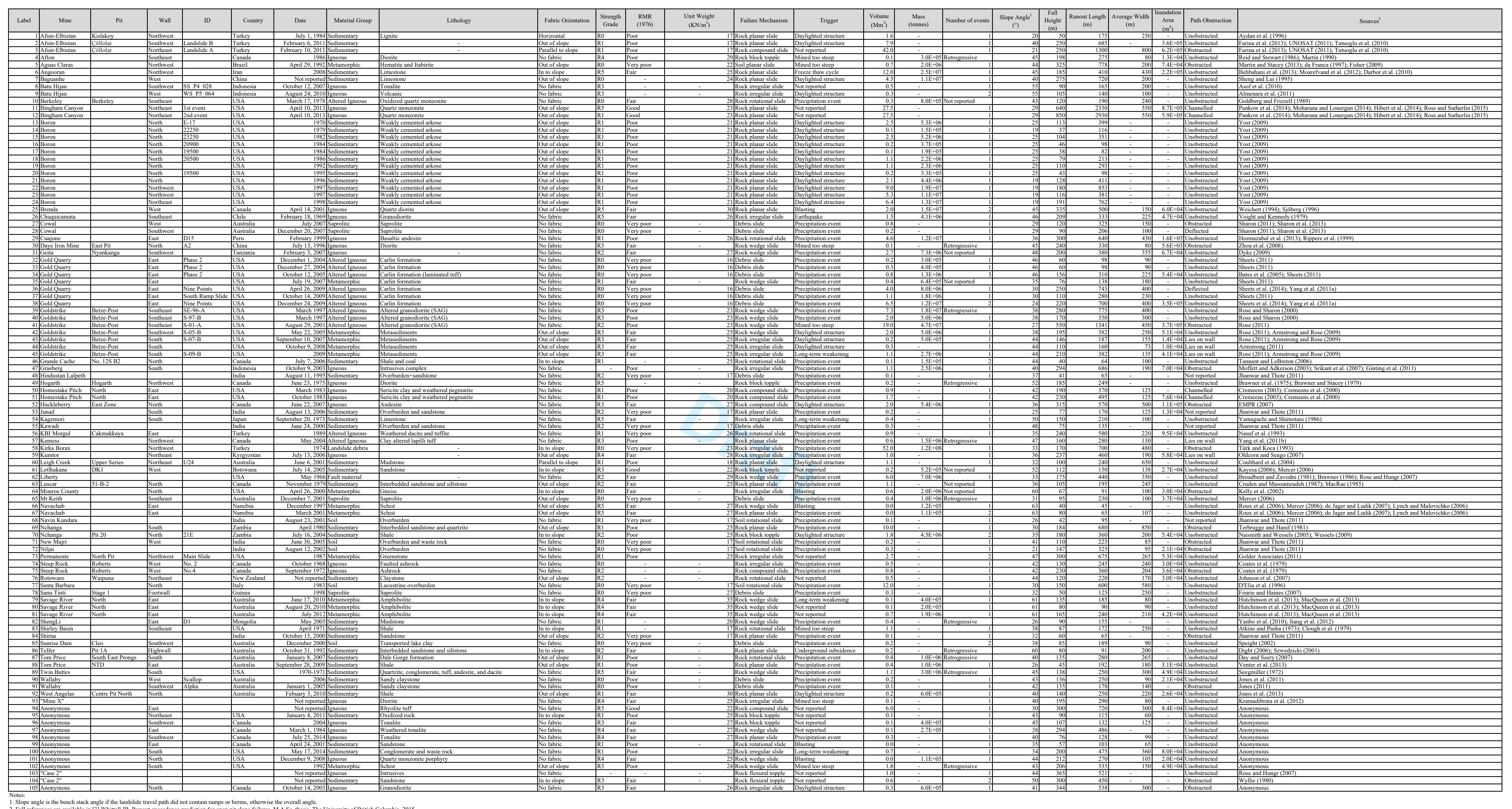

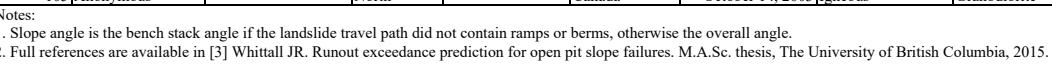




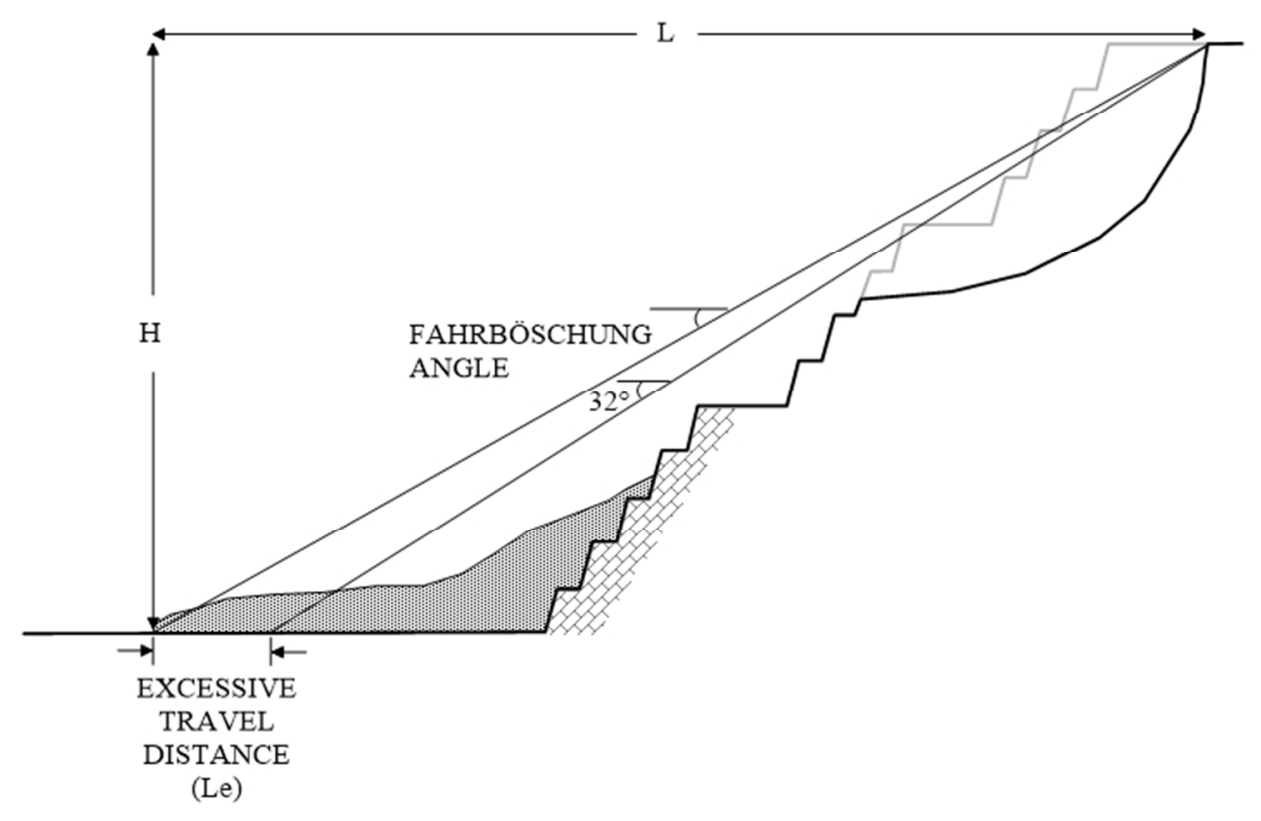

Schematic definition of the Fahrböschung angle and excessive travel distance Figure 1 $154 \times 98 \mathrm{~mm}$ (124 x 124 DPI) 


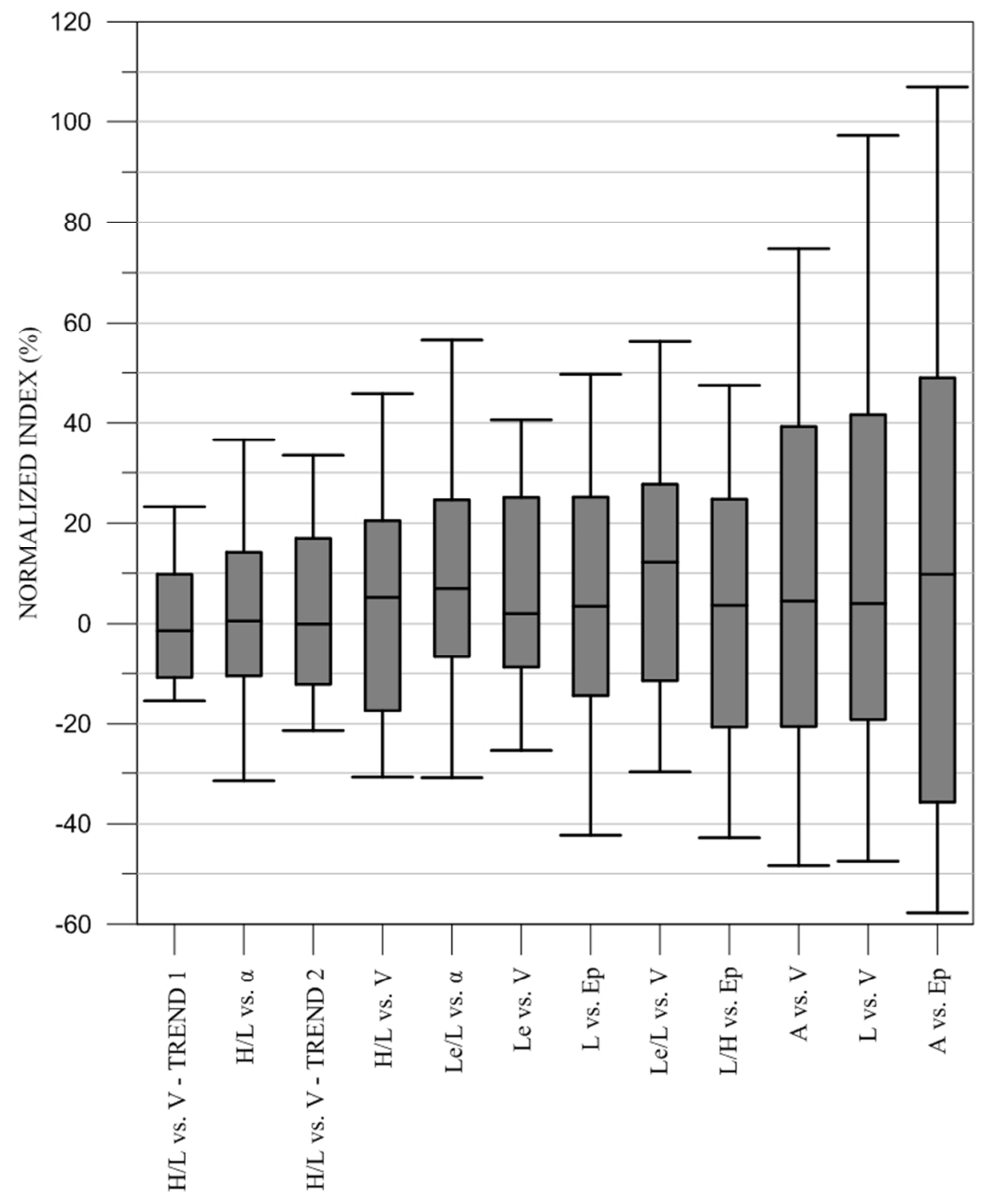

Prediction quality of runout relationships calibrated to open pit landslides Figure 2

$173 \times 200 \mathrm{~mm}(124 \times 124$ DPI $)$ 


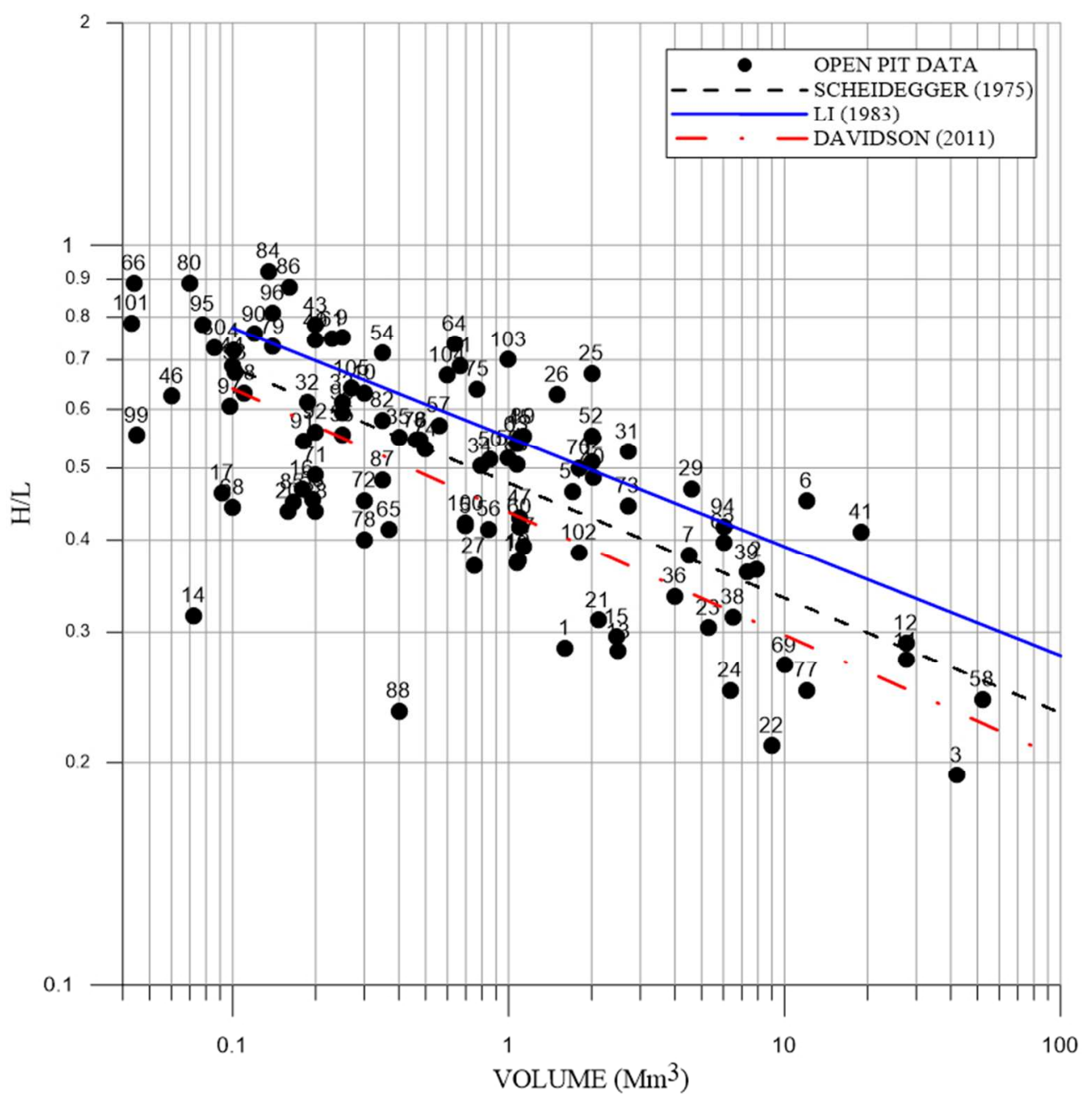

Open pit data with Scheidegger (1975), Li (1983), and Davidson (2011) best fit Fahrböschung angle vs. volume regressions

Figure 3

$172 \times 171 \mathrm{~mm}(124 \times 124 \mathrm{DPI})$ 


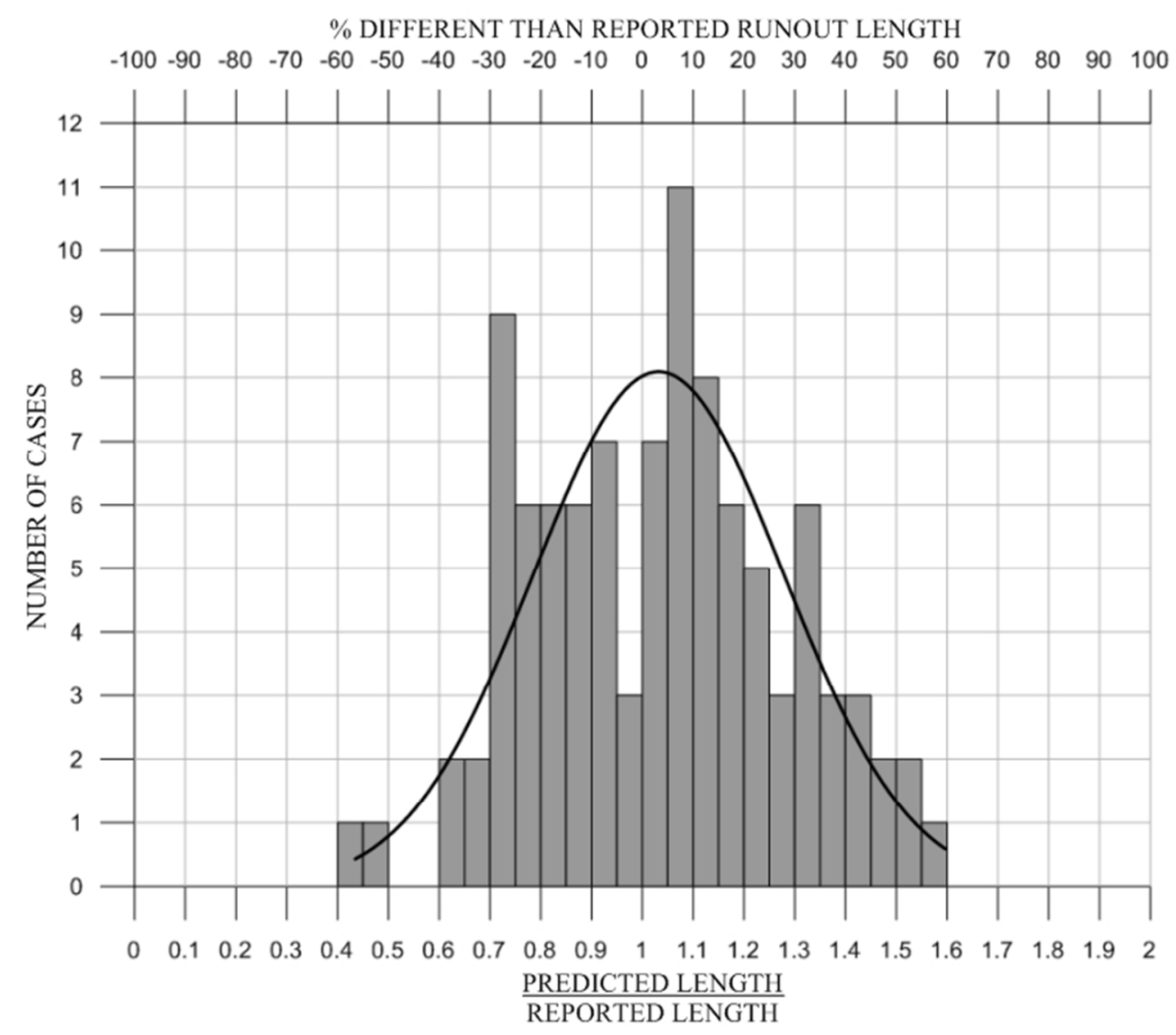

Error distribution for Fahrböschung angle vs. volume mobility relationship Figure 4

$153 \times 137 \mathrm{~mm}(124 \times 124$ DPI $)$ 


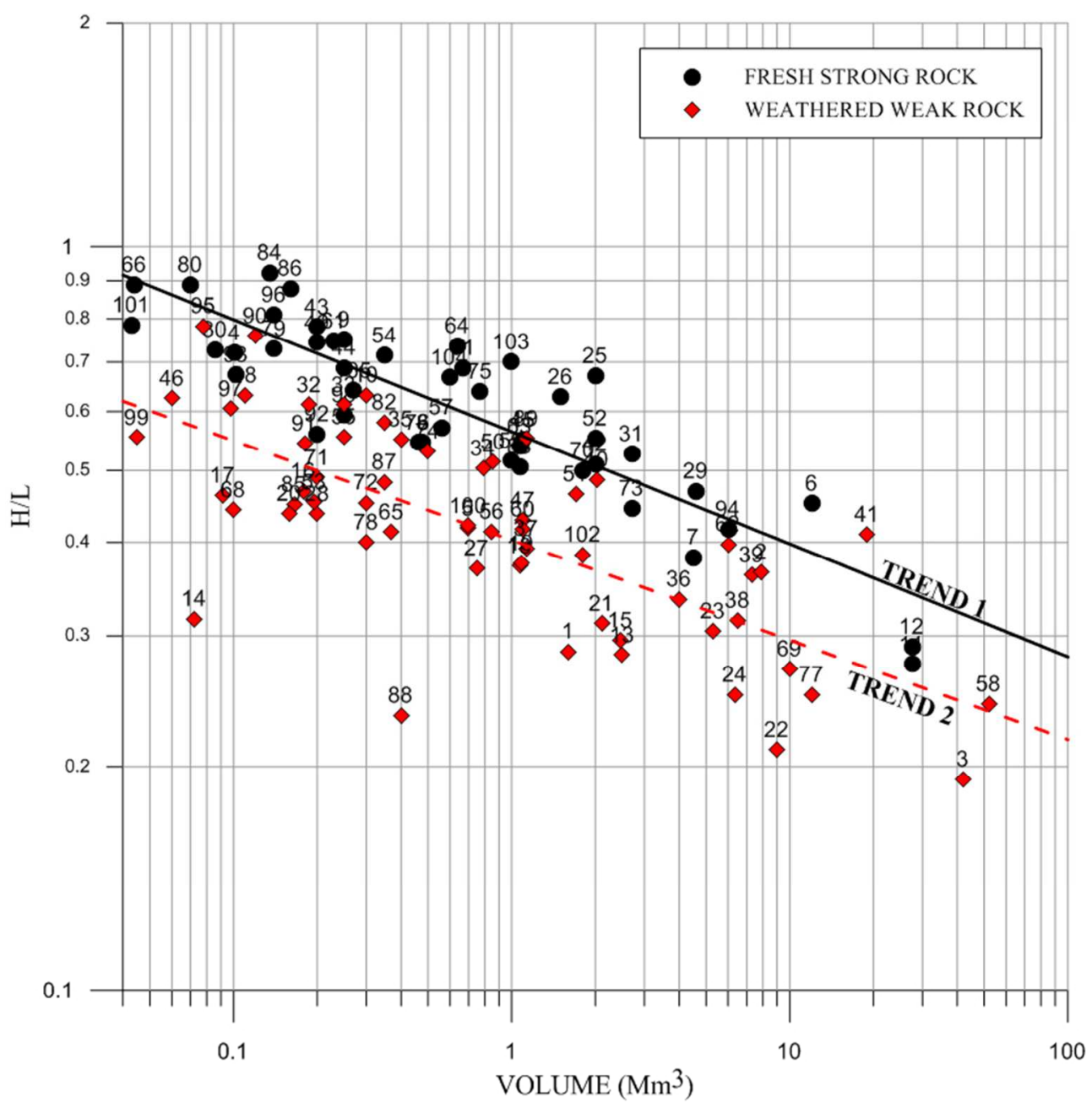

Open pit data with Fahrböschung angle vs. volume relationship. Two separate mobility trends emerge based on rock mass characteristics.

Figure 5

$172 \times 171 \mathrm{~mm}(124 \times 124 \mathrm{DPI})$ 


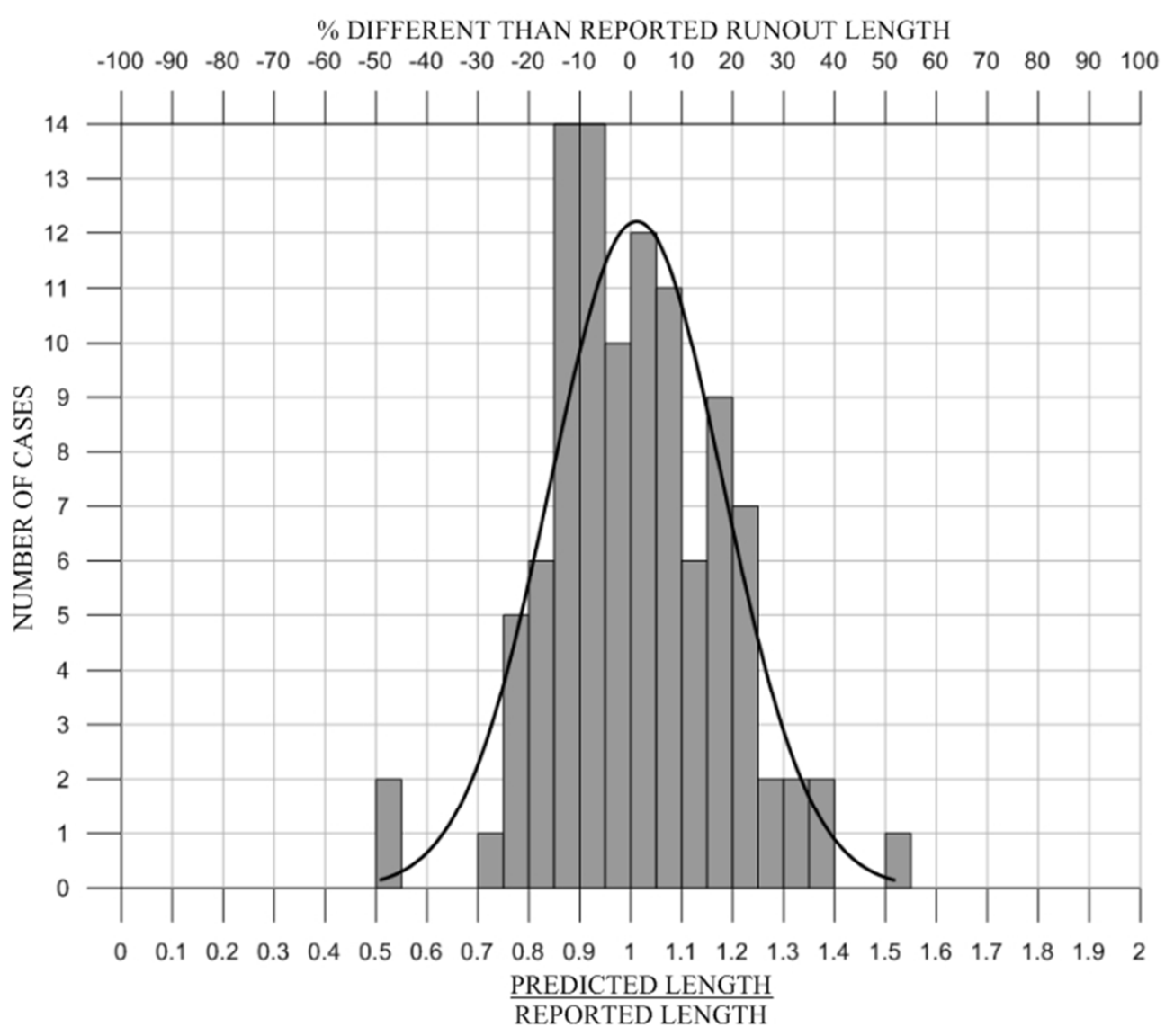

Error distribution for stratified Fahrböschung angle vs. volume mobility relationship Figure 6 $153 \times 135 \mathrm{~mm}(124 \times 124 \mathrm{DPI})$ 


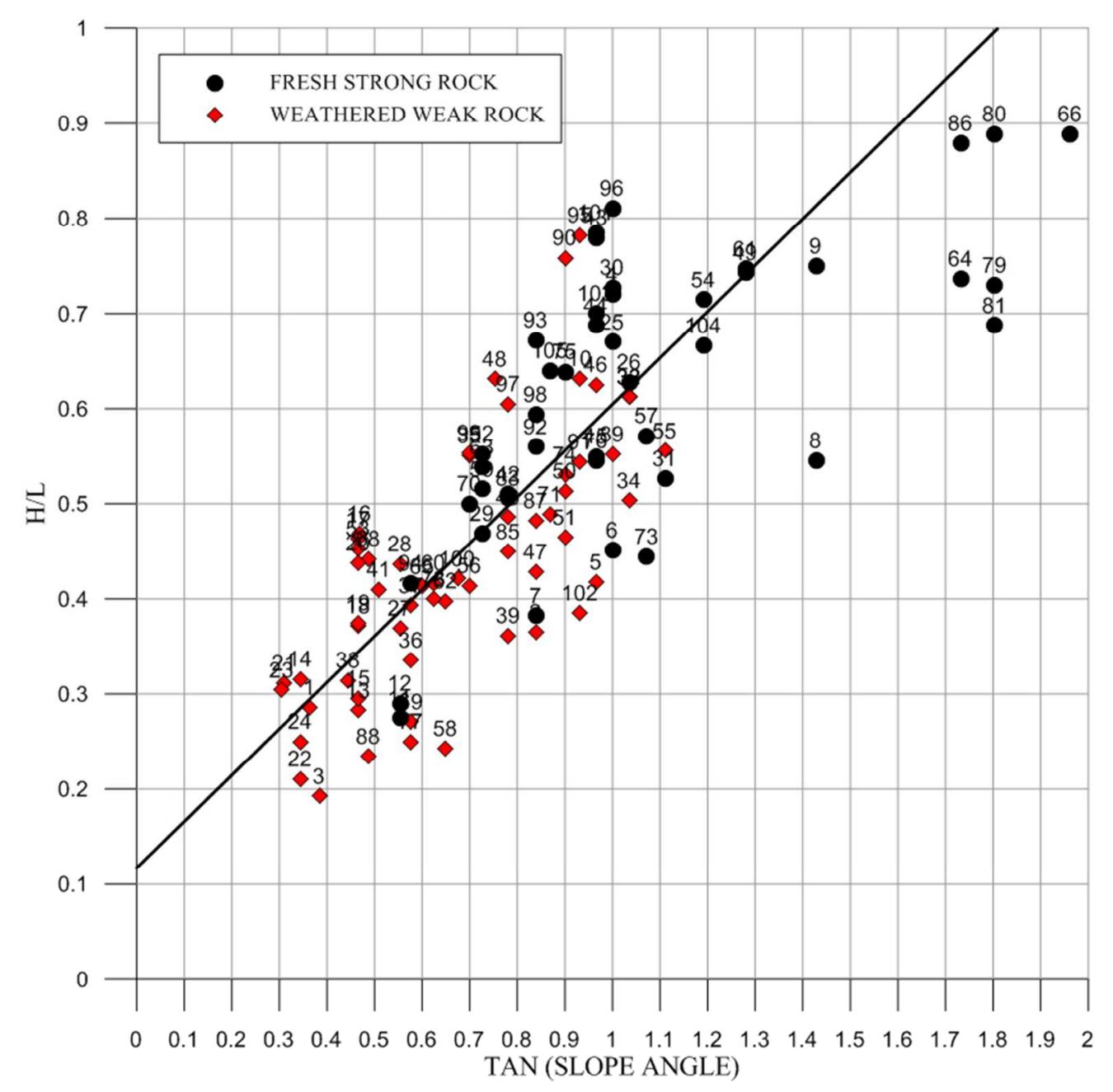

Open pit data with Fahrböschung angle vs. slope angle mobility relationship Figure 7

$171 \times 171 \mathrm{~mm}(124 \times 124 \mathrm{DPI})$ 


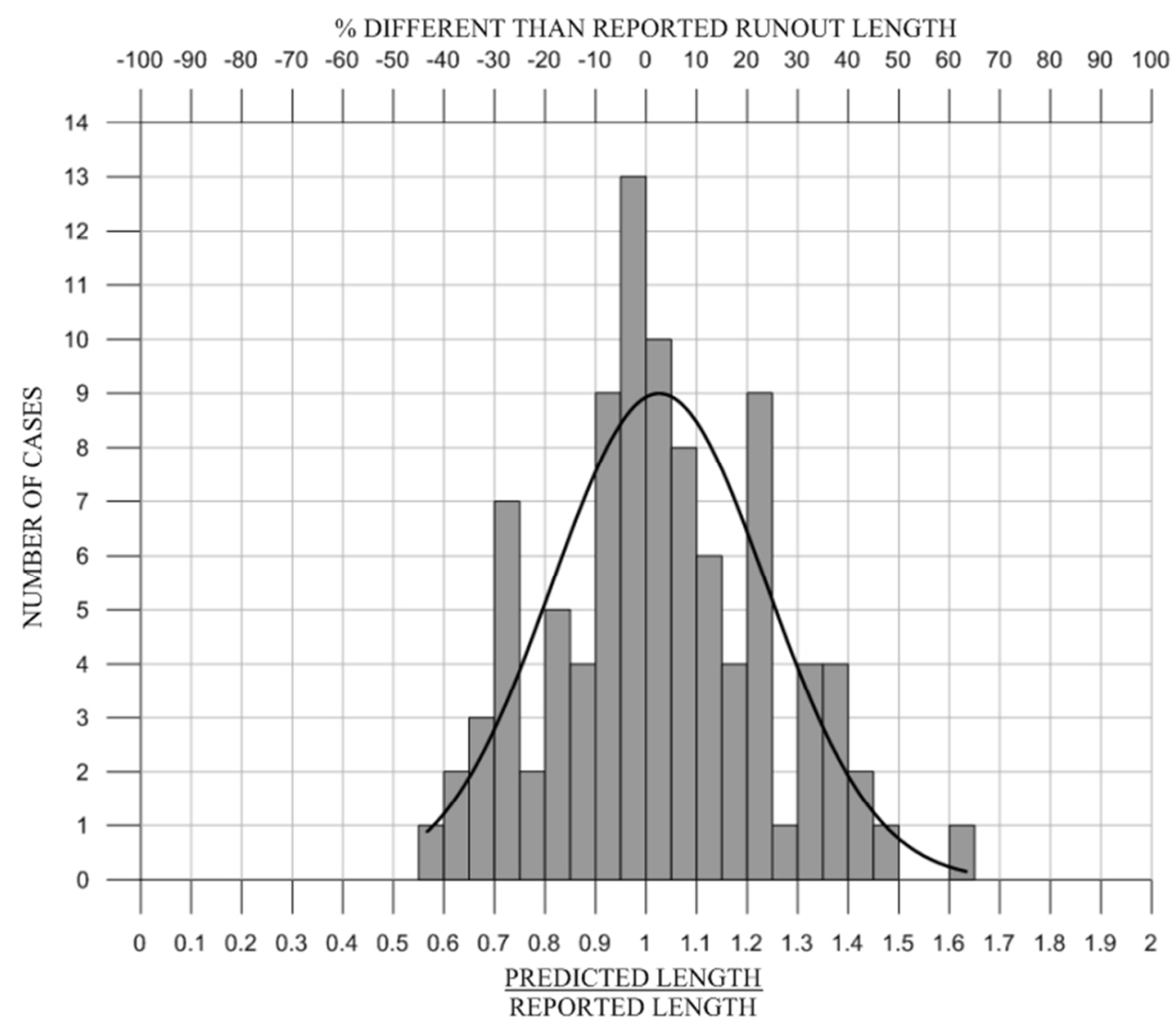

Error distribution for Fahrböschung angle vs. slope angle mobility relationship Figure 8 $156 \times 135 \mathrm{~mm}(124 \times 124$ DPI $)$ 


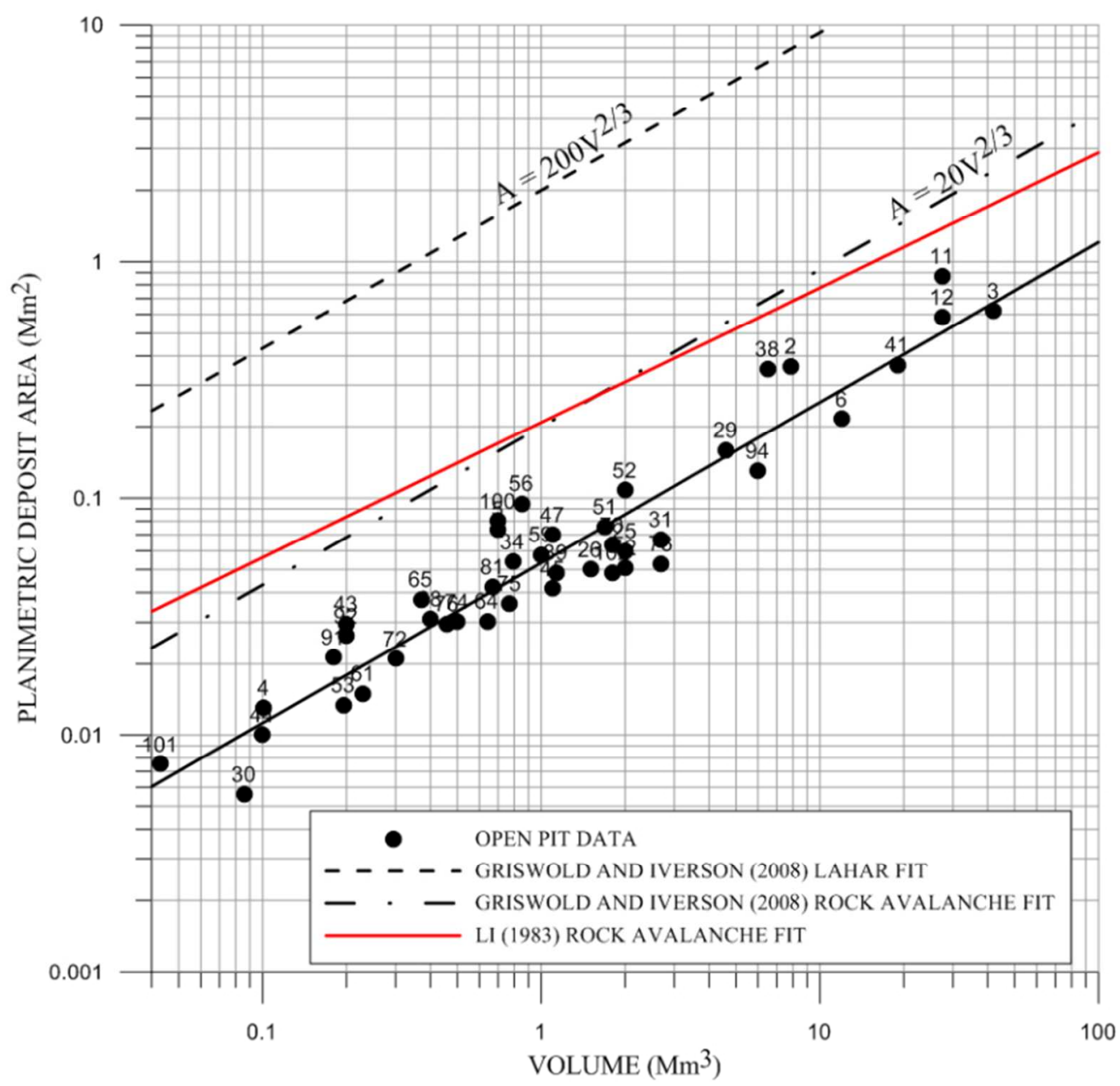

Open pit data with inundation area vs. volume mobility relationship Figure 9

$171 \times 166 \mathrm{~mm}(124 \times 124 \mathrm{DPI})$ 


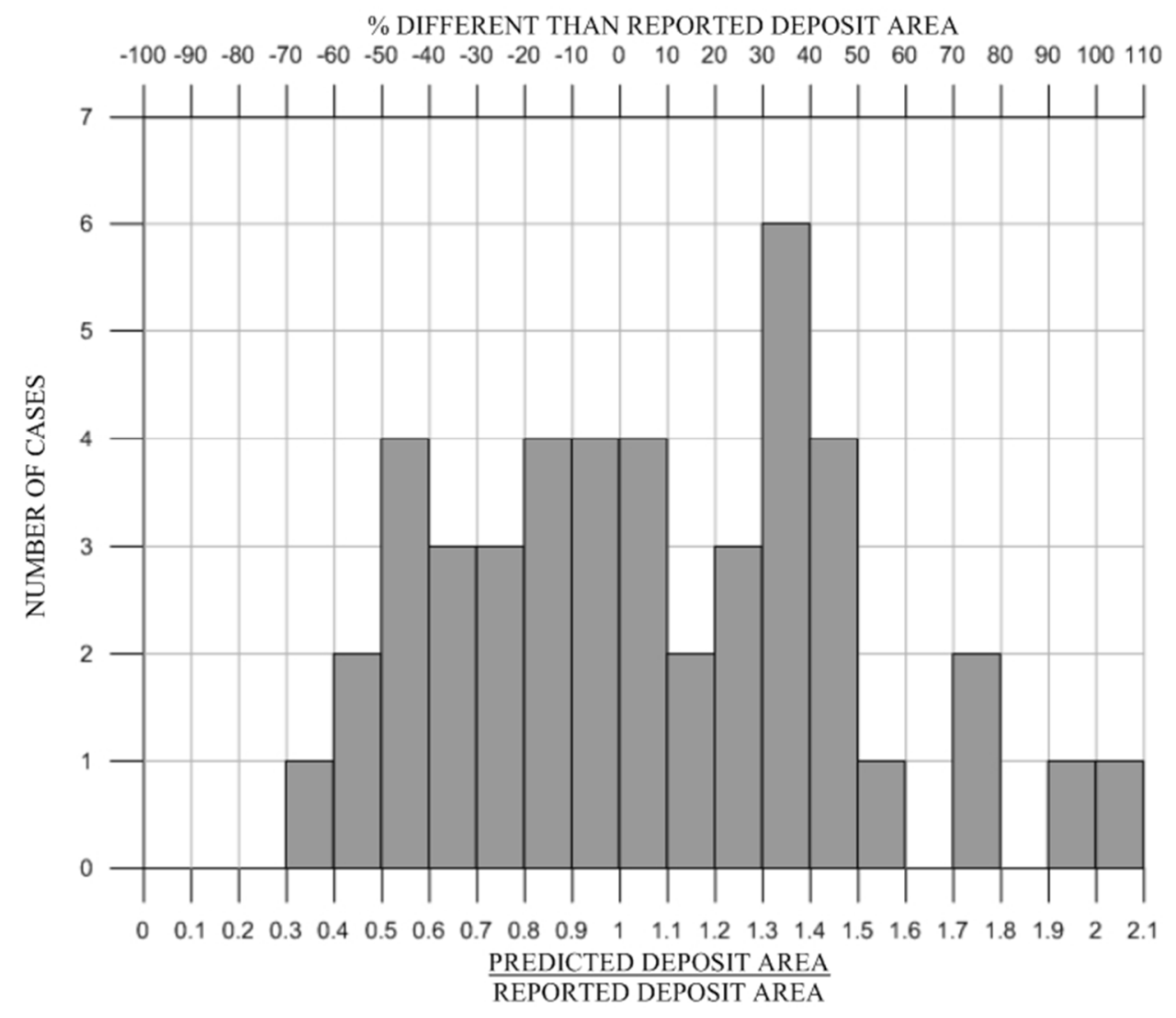

Error distribution for inundation area vs. volume mobility relationship Figure 10 $158 \times 139 \mathrm{~mm}(124 \times 124 \mathrm{DPI})$ 


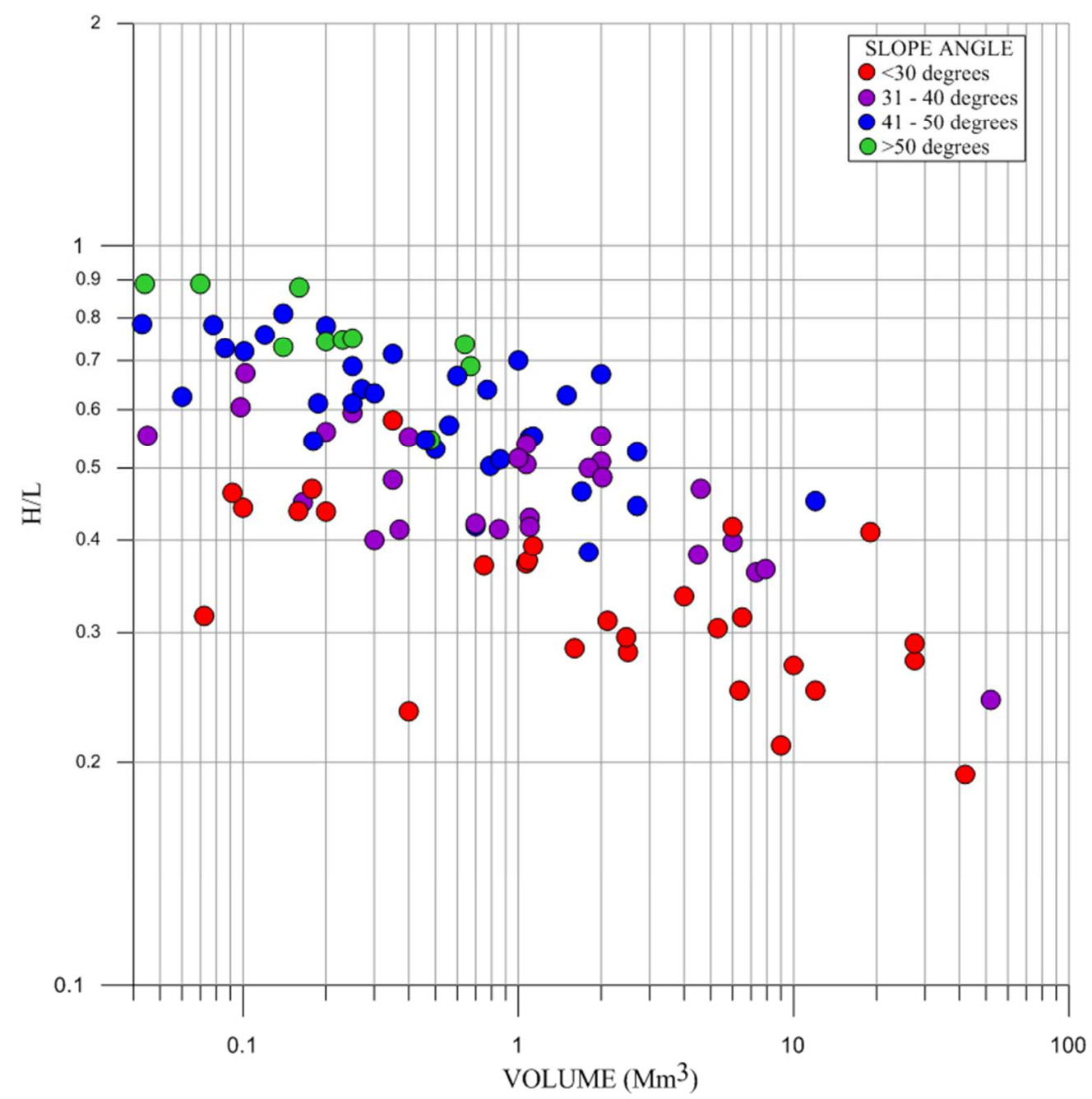

Fahrböschung angle vs. volume mobility relationship symbolized by slope angle Figure 11

$170 \times 171 \mathrm{~mm}(124 \times 124 \mathrm{DPI})$ 


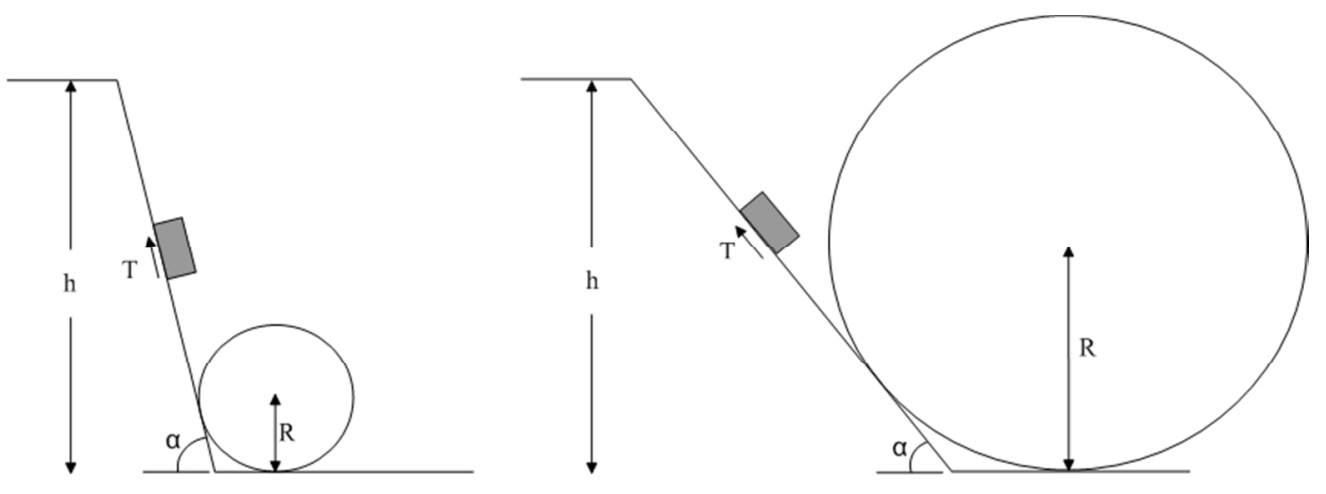

Exaggerated schematic of slope angle's effect on centripetal acceleration Figure 12

$174 \times 62 \mathrm{~mm}(124 \times 124 \mathrm{DPI})$ 


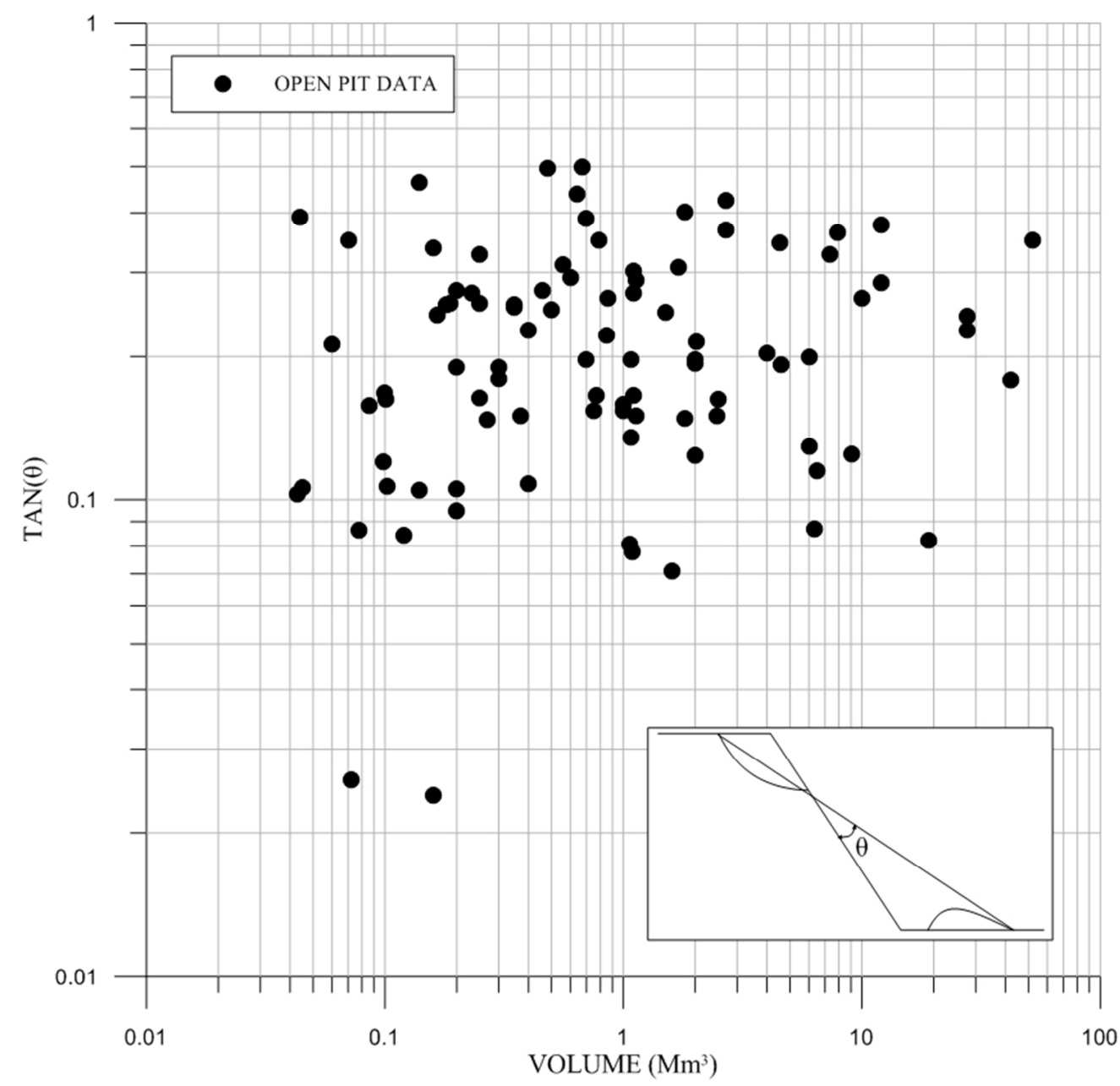

Open pit data with Fahrböschung angle normalized to slope angle. Note there is no relationship with volume when normalized to original slope angle.

Figure 13

$175 \times 170 \mathrm{~mm}(124 \times 124 \mathrm{DPI})$ 


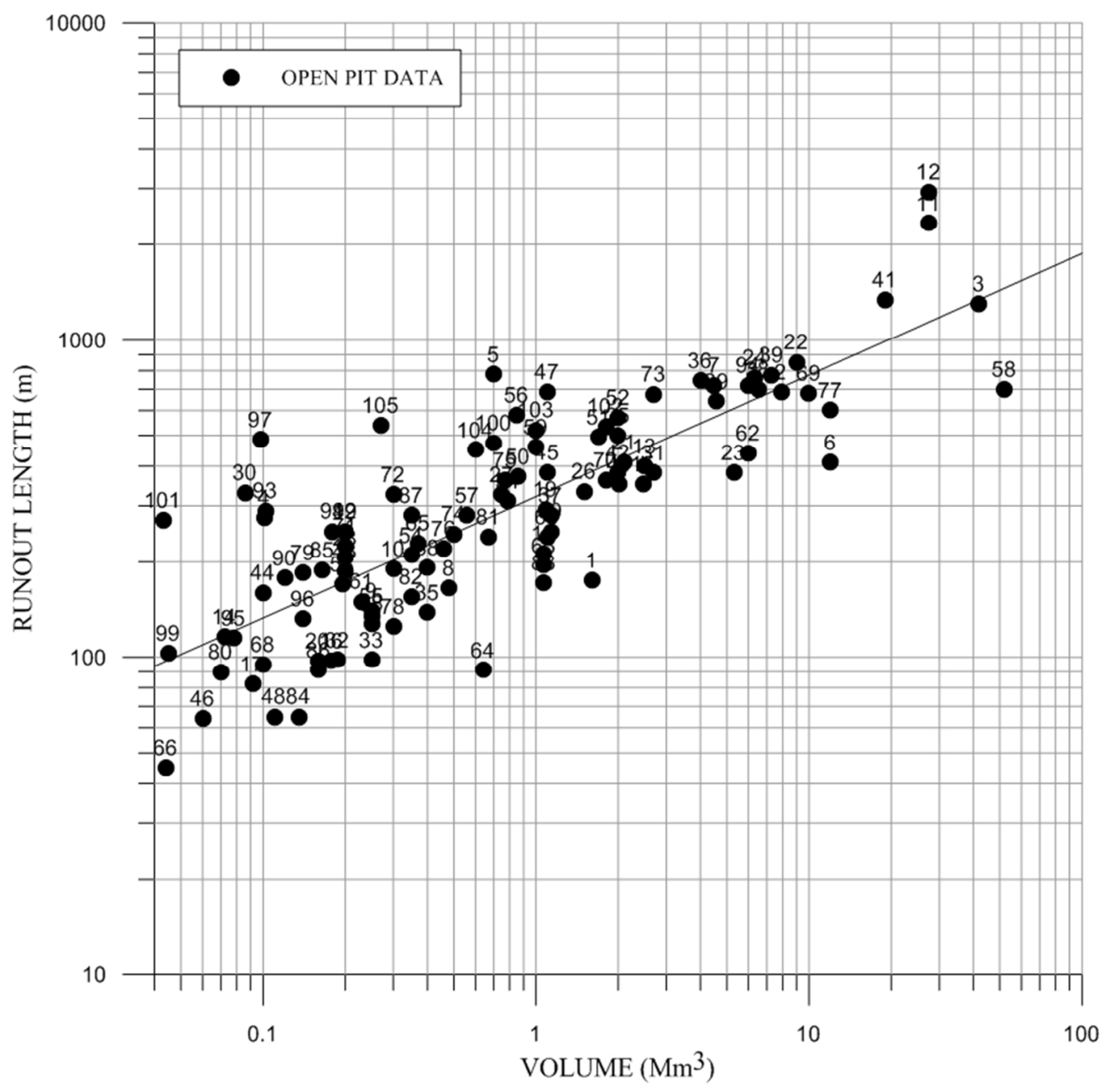

Open pit data with runout length vs. volume mobility relationship Figure 14

$174 \times 174 \mathrm{~mm}(124 \times 124 \mathrm{DPI})$ 


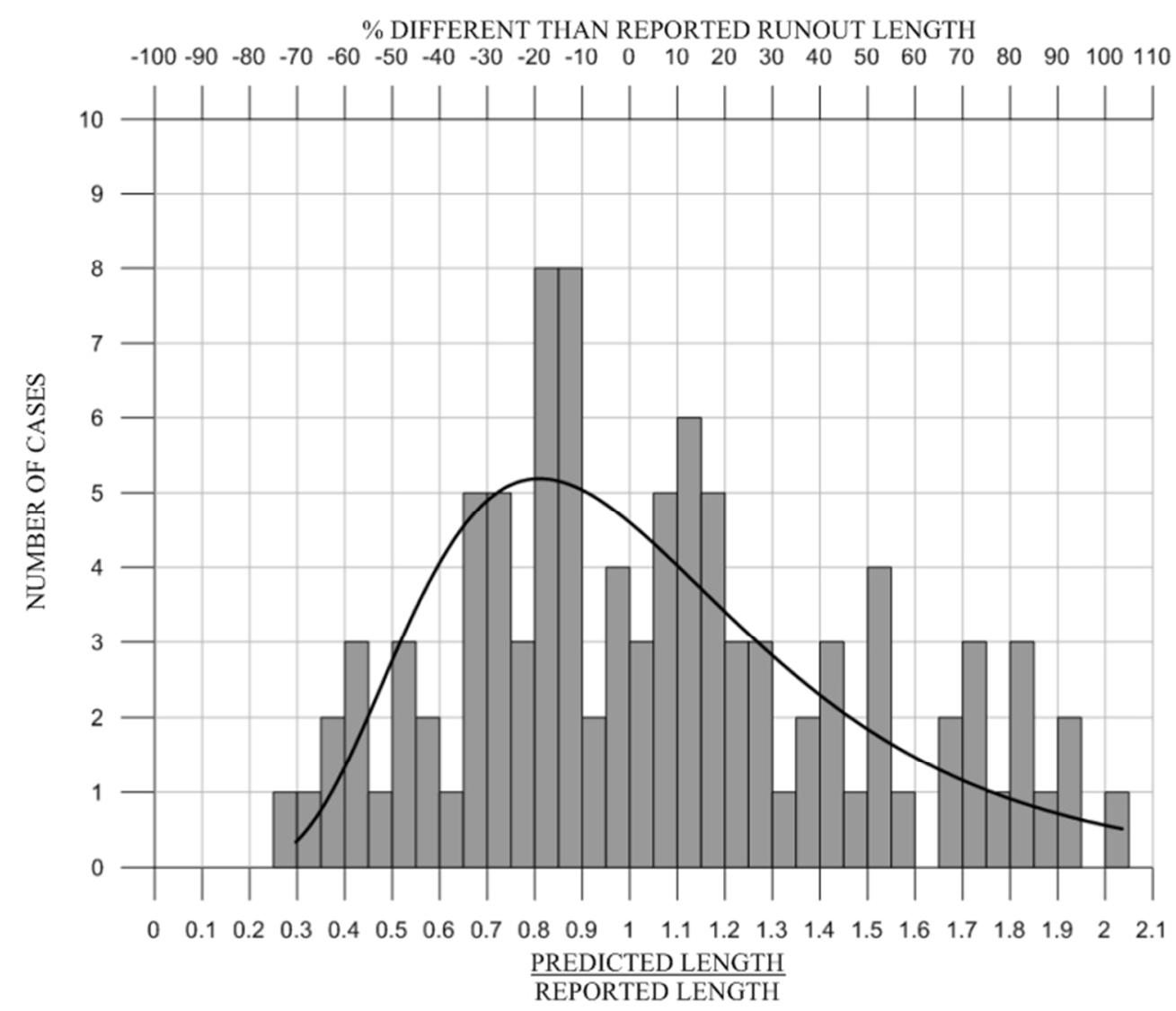

Distribution of error for runout length vs. volume mobility relationship Figure 15 $158 \times 135 \mathrm{~mm}(124 \times 124 \mathrm{DPI})$ 


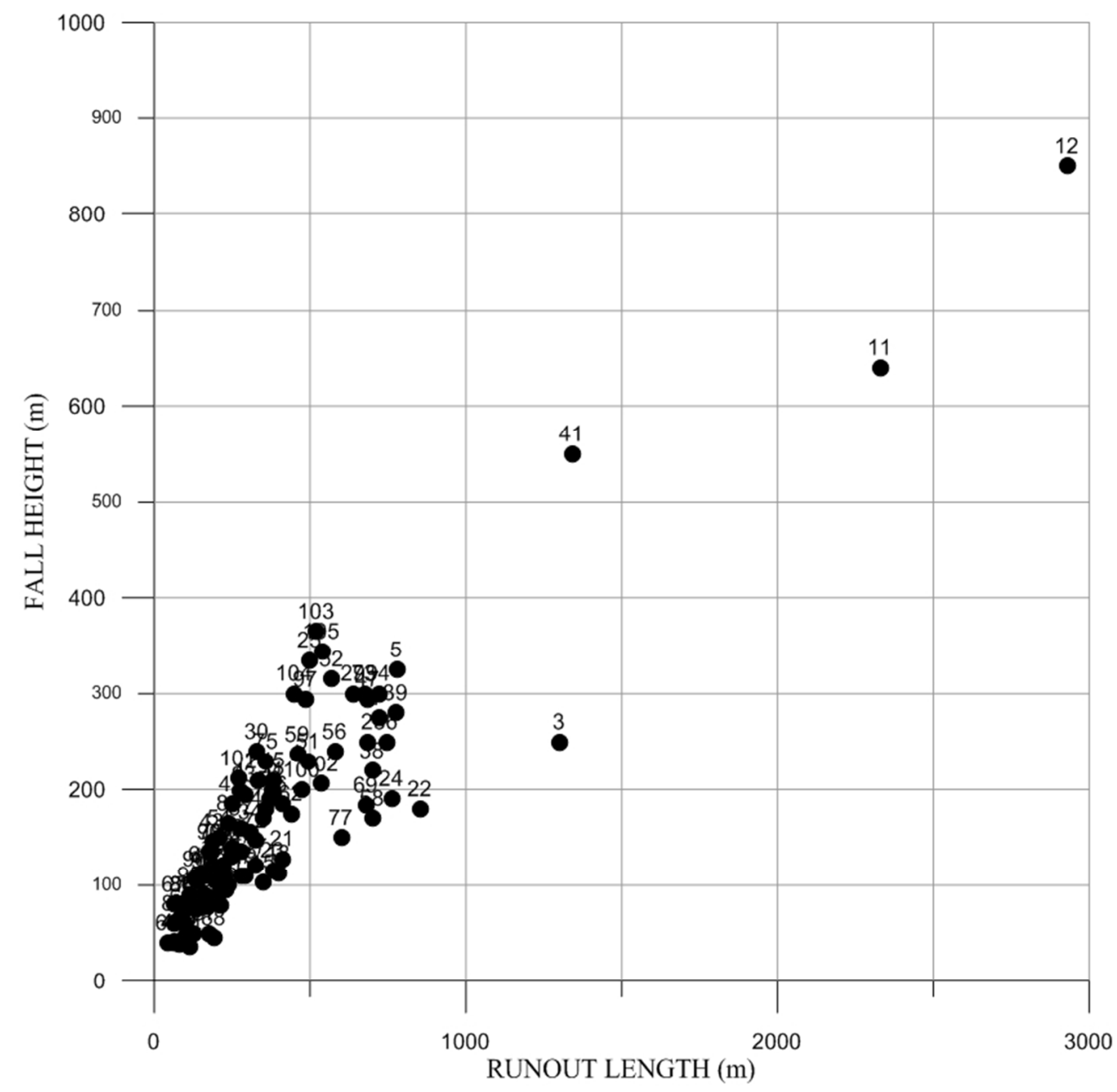

Comparison of open pit failure fall height to runout length

Figure 16

$174 \times 174 \mathrm{~mm}(124 \times 124 \mathrm{DPI})$ 


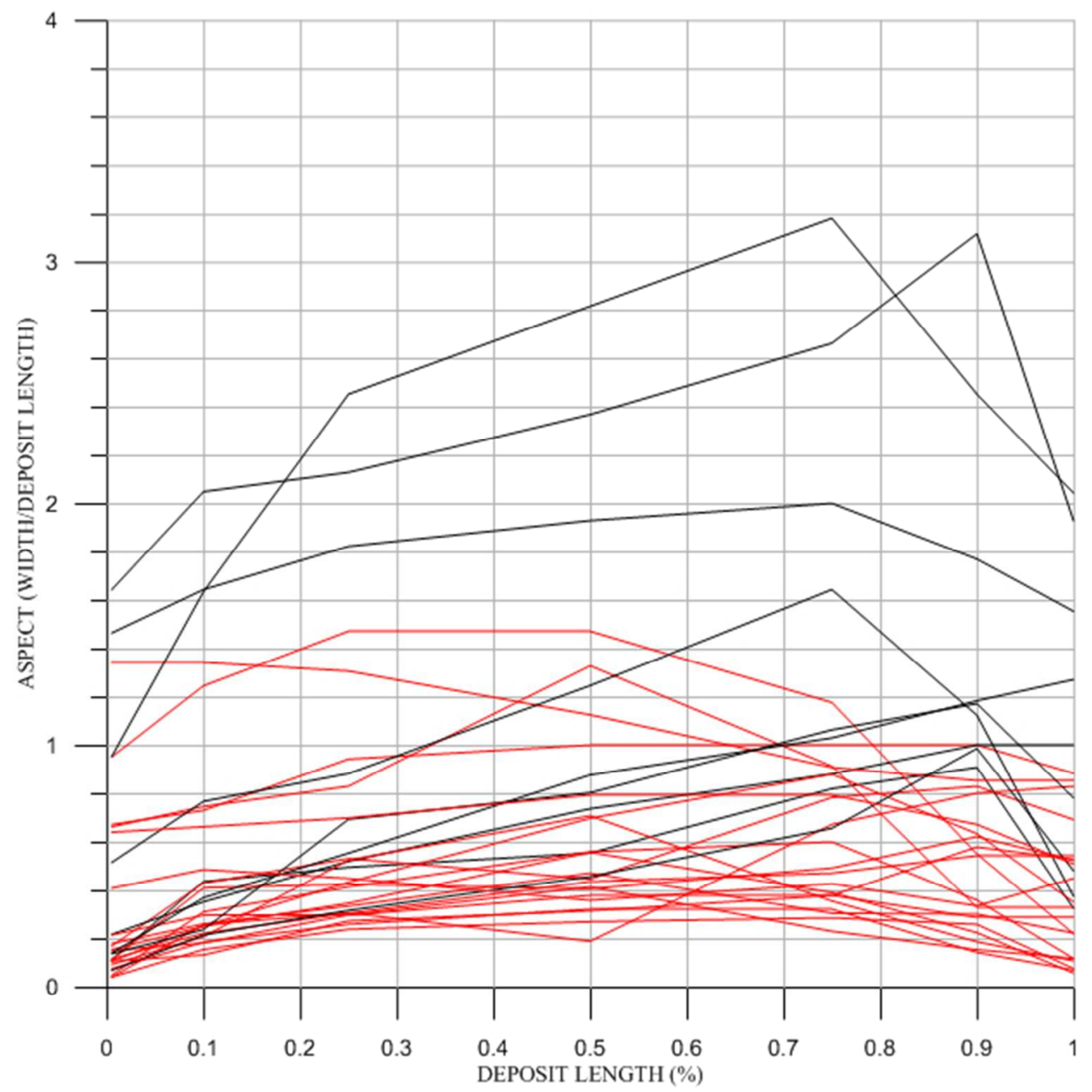

Map of deposit aspect observations

Figure 17

$167 \times 170 \mathrm{~mm}(96 \times 96$ DPI) 


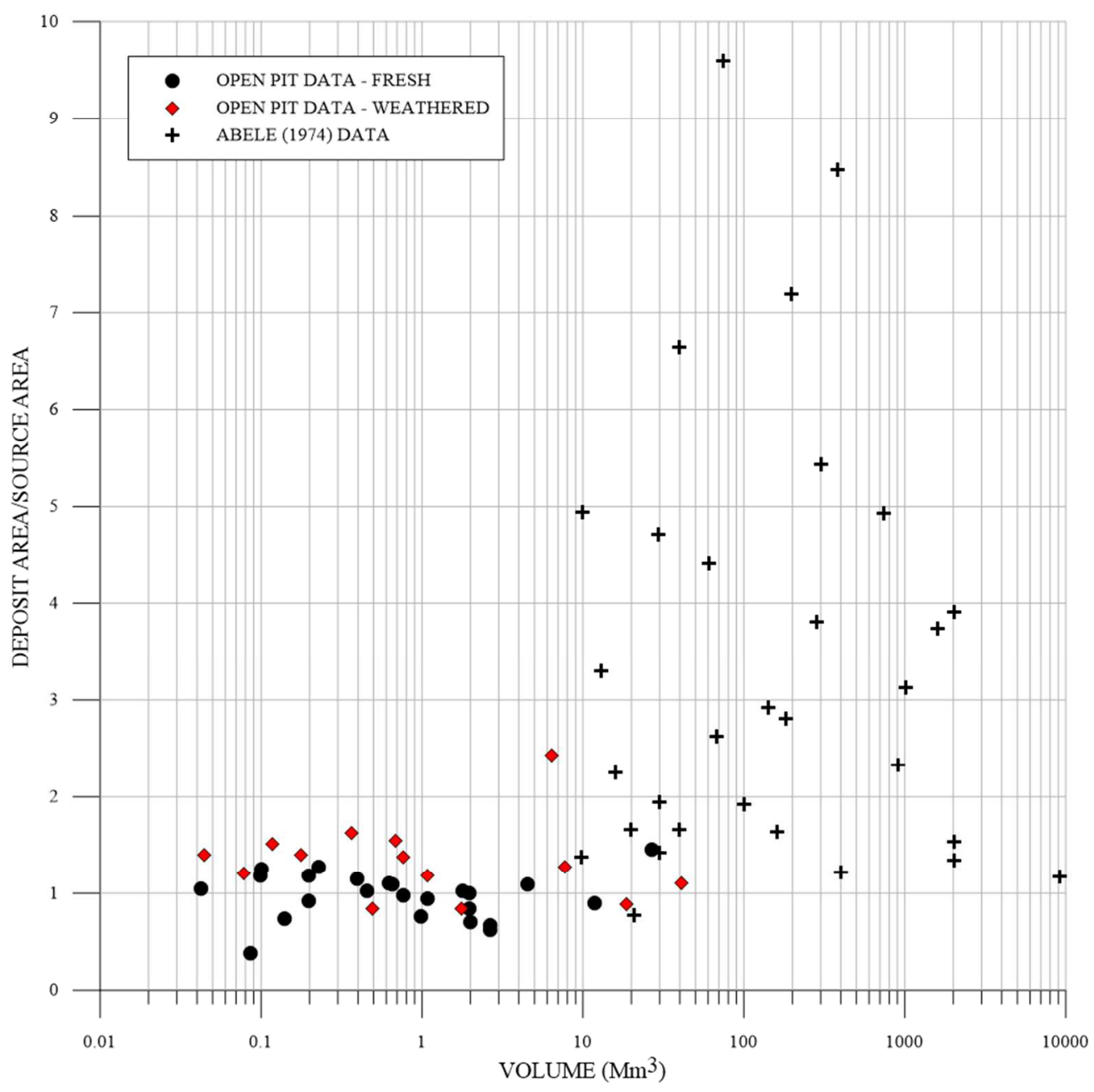

Degree of spreading in open pit slope failures Figure 18 $201 \times 199 \mathrm{~mm}(124 \times 124$ DPI $)$ 


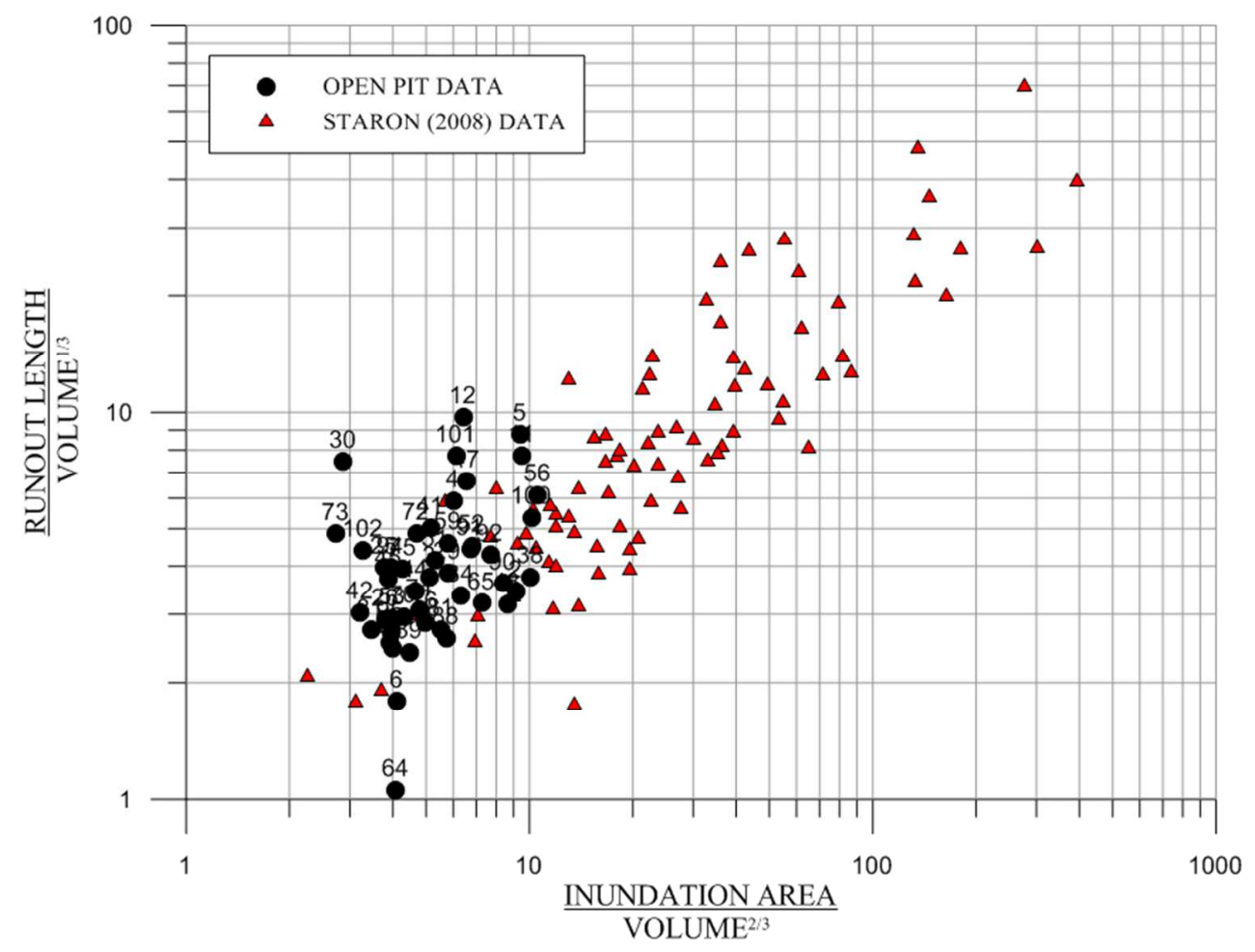

Open pit data with dimensionless mobility relationship Figure 19 $181 \times 136 \mathrm{~mm}(124 \times 124 \mathrm{DPI})$ 


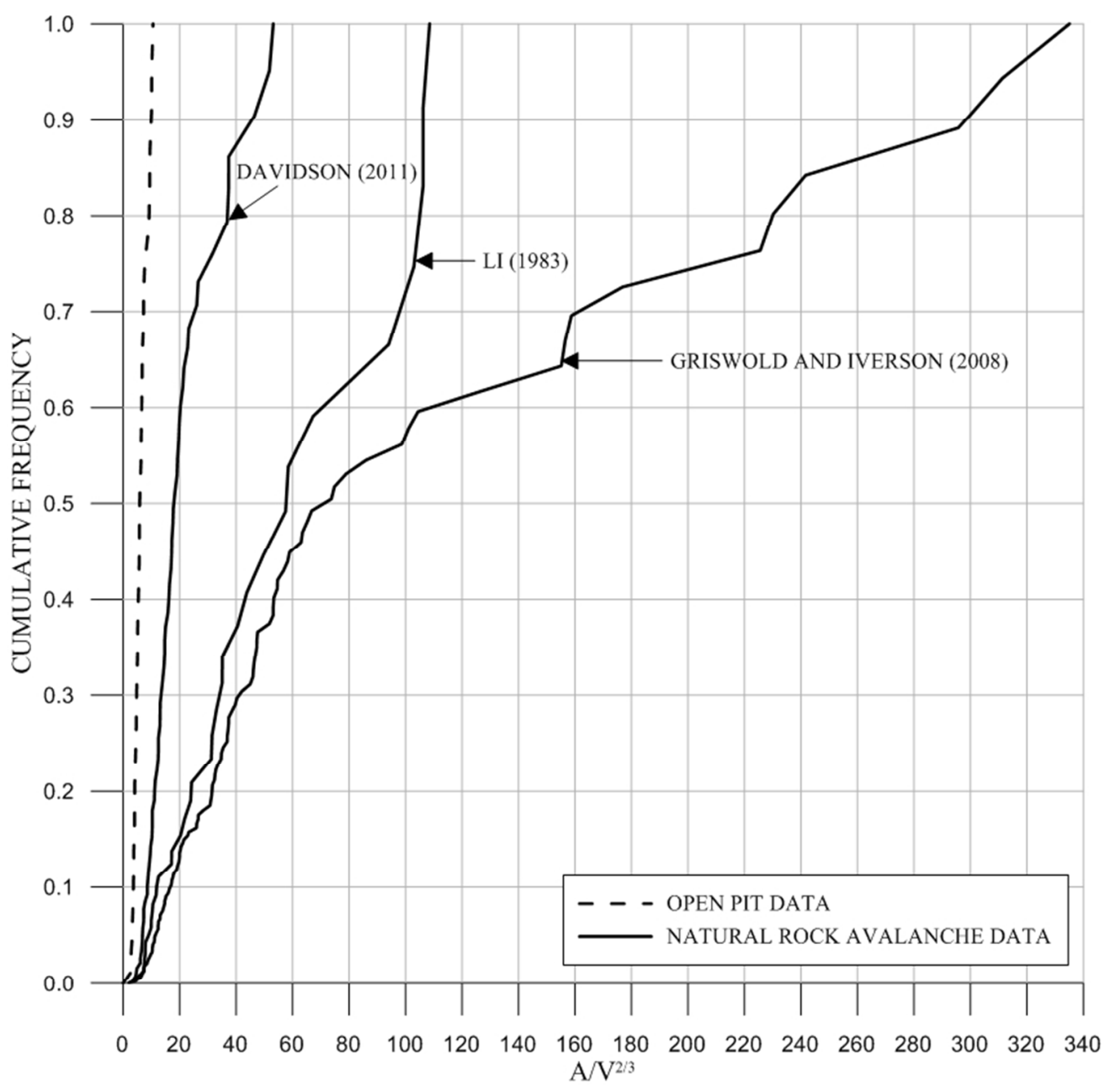

Comparison of open pit failure and natural rock avalanche deposit spreads Figure 20

$173 \times 170 \mathrm{~mm}(124 \times 124 \mathrm{DPI})$ 


\begin{tabular}{|c|c|c|c|c|c|c|}
\hline \multirow{2}{*}{\multicolumn{2}{|c|}{$\begin{array}{c}\text { Fahrböschung angle } \\
\text { trends: } \\
1 \text { - fresh, strong rocks } \\
2 \text { - weathered, weak rocks }\end{array}$}} & High & \multicolumn{3}{|c|}{ SHEAR STRENGTH } & \multirow[b]{2}{*}{\begin{tabular}{|l|}
\multicolumn{1}{c}{ Low } \\
- completely \\
weathered \\
- pre-sheared \\
- pervasive clay \\
infill
\end{tabular}} \\
\hline & & $\begin{array}{l}\text { - strong }(>\mathrm{R} 3) \\
\text { - fresh }\end{array}$ & $\begin{array}{l}\text { - strong }(>\mathrm{R} 3) \\
\text { - faintly } \\
\text { weathered }\end{array}$ & $\begin{array}{l}\text { - medium } \\
\text { strong (R2- } \\
\text { R3) } \\
\text { - slightly to } \\
\text { moderately } \\
\text { weathered }\end{array}$ & $\begin{array}{l}\text { - weak }(<\mathrm{R} 2) \\
\text { - moderate to } \\
\text { highly } \\
\text { weathered } \\
\text { - clay infilled } \\
\text { joints }\end{array}$ & \\
\hline \multirow{5}{*}{ STRUCTURE } & $\begin{array}{l}\text { - massive } \\
\text { - low porosity }\end{array}$ & & & & & \\
\hline & $\begin{array}{l}\text { - jointed } \\
\text { minor } \\
\text { secondary } \\
\text { porosity }\end{array}$ & & TREND 1 & & & \\
\hline & $\begin{array}{l}\text { - jointed } \\
\text { priquitous } \\
\text { primary or } \\
\text { secondary } \\
\text { porosity }\end{array}$ & & & & & \\
\hline & $\begin{array}{l}\text { - faulted } \\
\text { - ubiquitous } \\
\text { primary or } \\
\text { secondary } \\
\text { porosity }\end{array}$ & & & & TREND 2 & \\
\hline & $\begin{array}{l}\text { - confluence of } \\
\text { faults } \\
\text { - brecciated } \\
\text { - ubiquitous } \\
\text { porosity } \\
\text { - no/poor } \\
\text { cementation }\end{array}$ & N/A & & & & \\
\hline
\end{tabular}

Rock mass characteristics mobility trends matrix for use with Figure 5 Figure 21

$101 \times 95 \mathrm{~mm}(144 \times 144$ DPI $)$ 


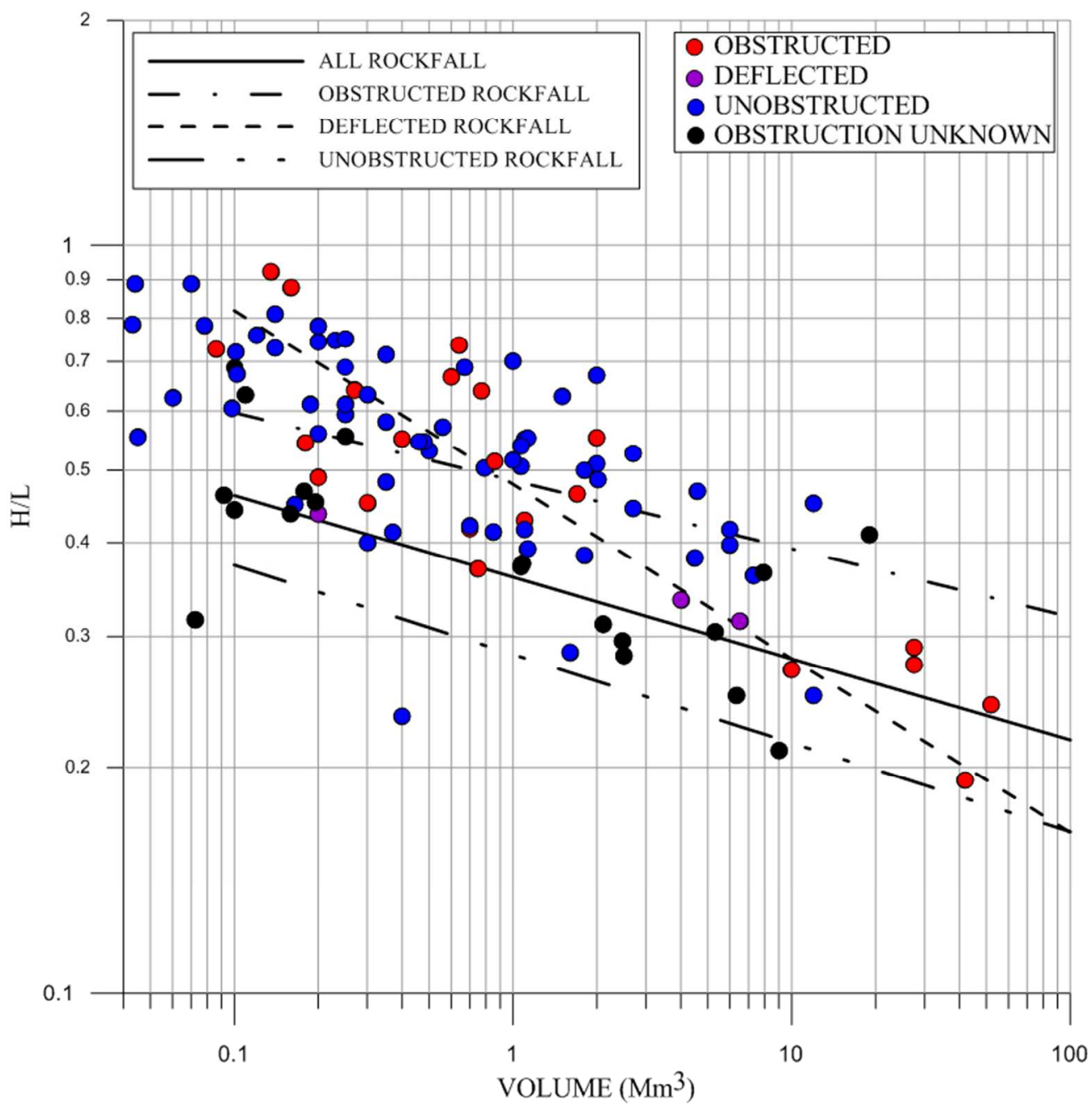

Open pit data compared to Corominas (1996) path obstruction Fahrböschung angle vs. volume mobility relationship

Figure 22

$170 \times 171 \mathrm{~mm}(124 \times 124 \mathrm{DPI})$ 


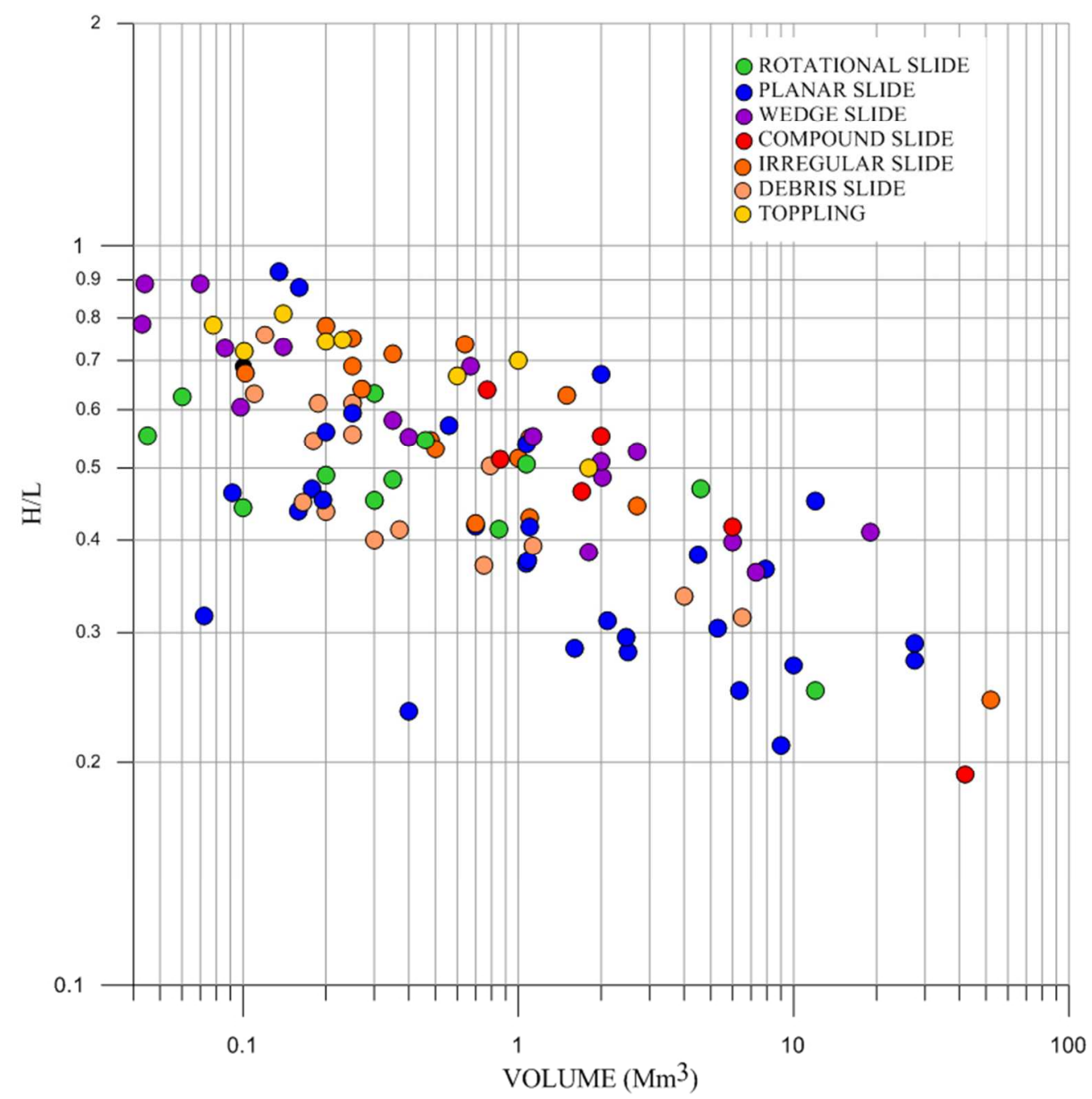

Fahrböschung angle vs. volume relationship symbolized by failure mechanism Figure 23

$170 \times 171 \mathrm{~mm}(124 \times 124 \mathrm{DPI})$ 
Table 1. Mobility relationship comparison, where $A$ is the planimetric inundation area, $V$ is the source volume, $\alpha$ is the original wall angle, and $H, L$ and

Le are defined in Figure 1

\begin{tabular}{|c|c|c|c|c|c|c|c|}
\hline Input & $\begin{array}{l}\text { Mobility } \\
\text { relationship }\end{array}$ & Best fit equation & $\mathrm{RMSE}^{*}$ & $\begin{array}{c}\text { Mean } \\
\text { NI } \\
(\%)\end{array}$ & $\begin{array}{c}\text { Error } \\
\text { distribution }\end{array}$ & $\begin{array}{c}\text { Parameter } \\
\text { sensitivity }{ }^{\dagger} \\
(\%)\end{array}$ & Source \\
\hline & $\mathrm{H} / \mathrm{L}$ & $\mathrm{H} / \mathrm{L}=0.463 \mathrm{~V}^{-0.148}$ & 109 & 3.2 & Normal & 11 & \\
\hline & $\mathrm{H} / \mathrm{L}($ trend 1$)$ & $\mathrm{H} / \mathrm{L}=0.559 \mathrm{~V}^{-0.150}$ & 48 & 0.8 & Normal & 11 & Heim (1932) \\
\hline
\end{tabular}

Volume 